Review

www.mdpi.com/journal/energies

\title{
Enhanced Oil Recovery: An Update Review
}

\section{Vladimir Alvarado $^{1, *}$ and Eduardo Manrique ${ }^{2}$}

1 Department of Chemical and Petroleum Engineering, University of Wyoming, Department 3295, 1000 E. University Ave, Laramie, WY, USA

2 TIORCO (NALCO \& STEPAN Company), 2452 Trenton Way, Suite M, Denver, CO 80231, USA; E-Mail: ejmanrique@tiorco.com

* Author to whom correspondence should be addressed; E-Mail: valvarad@uwyo.edu; Tel.: +1-307-766-6464; Fax: +1-307-766-6777.

Received: 27 June 2010 / Accepted: 10 August 2010 / Published: 27 August 2010

\begin{abstract}
With the decline in oil discoveries during the last decades it is believed that EOR technologies will play a key role to meet the energy demand in years to come. This paper presents a comprehensive review of EOR status and opportunities to increase final recovery factors in reservoirs ranging from extra heavy oil to gas condensate. Specifically, the paper discusses EOR status and opportunities organized by reservoir lithology (sandstone and carbonates formations and turbiditic reservoirs to a lesser extent) and offshore and onshore fields. Risk and rewards of EOR methods including growing trends in recent years such as $\mathrm{CO}_{2}$ injection, high pressure air injection (HPAI) and chemical flooding are addressed including a brief overview of $\mathrm{CO}_{2}$-EOR project economics.
\end{abstract}

Keywords: enhanced oil recovery; EOR; reservoir lithology; $\mathrm{CO}_{2}$; steam injection; air injection; chemical flooding

\section{EOR Status}

Most of the current world oil production comes from mature fields. Increasing oil recovery from the aging resources is a major concern for oil companies and authorities. In addition, the rate of replacement of the produced reserves by new discoveries has been declining steadily in the last decades. Therefore, the increase of the recovery factors from mature fields under primary and secondary production will be critical to meet the growing energy demand in the coming years. 
Improved Oil Recovery (IOR) methods encompass Enhanced Oil Recovery (EOR) methods as well as new drilling and well technologies, intelligent reservoir management and control, advanced reservoir monitoring techniques and the application of different enhancements of primary and secondary recovery processes. However, the present paper presents a comprehensive review of EOR status and opportunities to increase oil recoveries and final recovery factors in reservoirs ranging from extra heavy oil to gas condensate.

It is well known that EOR projects have been strongly influenced by economics and crude oil prices. The initiation of EOR projects depends on the preparedness and willingness of investors to manage EOR risk and economic exposure and the availability of more attractive investment options.

In the U.S., chemical and thermal EOR projects have been in constant decline from mid 1980's to 2005 (Figure 1). It is important to indicate that statistics on EOR activity is often masked because it goes unreported. In this article, all statistics and reports are based on available data from published articles, conference proceedings and other references. EOR gas injection project statistics remained constant since mid 1908's and exhibited a growing trend since year 2000, especially with the increase of $\mathrm{CO}_{2}$ projects. Indeed, since 2002 EOR gas injection projects outnumber thermal projects for the first time in the last three decades. However, thermal projects have shown a slightly increase since 2004 due to the increase of High Pressure Air Injection (HPAI) projects in light oil reservoirs. Chemical EOR methods still have not captured the interest of oil companies with only two projects reported in 2008 [1-5,7-18]. However, there is an increase in EOR chemical projects in the U.S. and abroad that have not been documented in the literature for different reasons that will be discussed later in the paper.

Figure 1. Evolution of EOR projects in the United States (From Oil \& Gas Journal EOR Surveys 1976-2010).

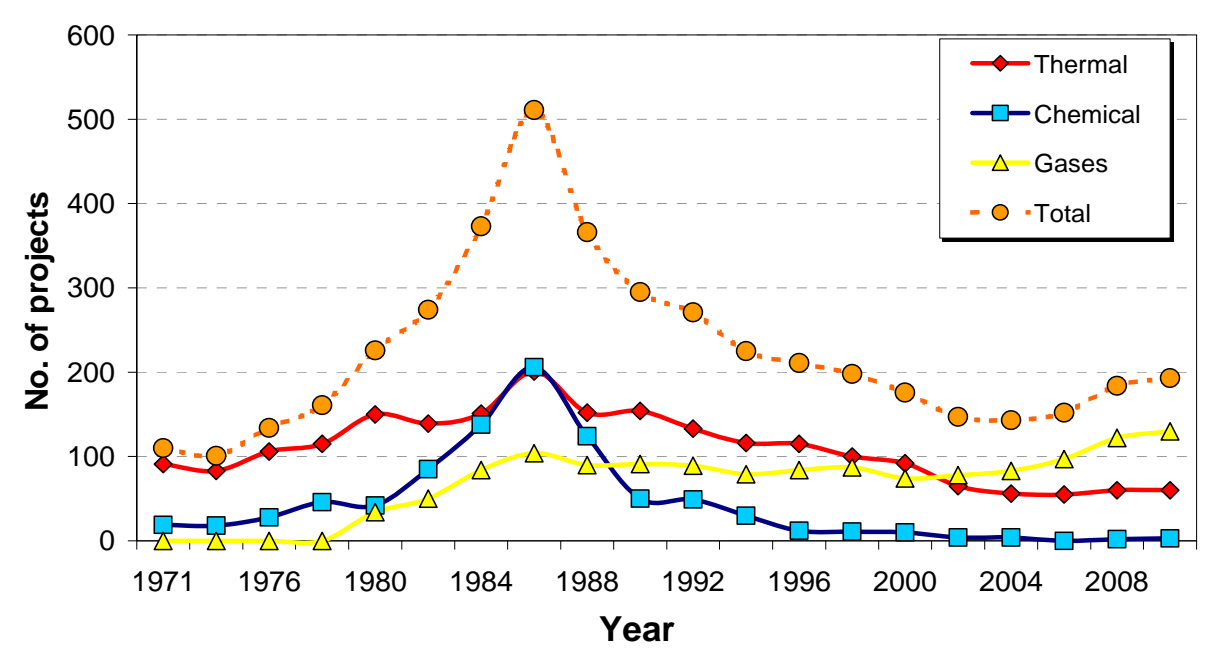

One of the reasons to explain the increase in U.S. EOR gas injection methods is due to vast sources of cheap sources of $\mathrm{CO}_{2}$ from natural sources (\$US 1-2/Mscf) and a readily available $\mathrm{CO}_{2}$ pipeline system making $\mathrm{CO}_{2}$ EOR projects economically attractive at oil prices around \$US 20 per barrel [19,20]. However, it is important to remark that the $\mathrm{CO}_{2}$ pipeline system in the U.S. was built in a 30 years (1975-2005) time span when oil prices and tax incentives were sufficiently attractive to ensure security of supply as main drivers as recently reported by Hustad [21]. On the other hand, the existing pipelines are privately own and this can be interpreted as a competitive advantage, but we cannot 
estimate the potential benefits or impact of privately vs. publicly owned $\mathrm{CO}_{2}$ pipelines on future $\mathrm{CO}_{2}$-EOR and/or storage markets. Figure 2 shows evolution of $\mathrm{CO}_{2}$ projects in the U.S. and average crude oil prices for the last 28 years. Oil price used are the refiner average domestic crude oil acquisition cost reported by the Energy Information Administration [22]. For reference purposes, crude oil price used in Figure 2 was arbitrarily selected for every month of June except for year 2010 (oil price as of March 2010).

Figure 2. Evolution of $\mathrm{CO}_{2}$ projects and oil prices in the U.S. (From Oil \& Gas Journal EOR Surveys 1980-2010 and U.S. EIA 2010).

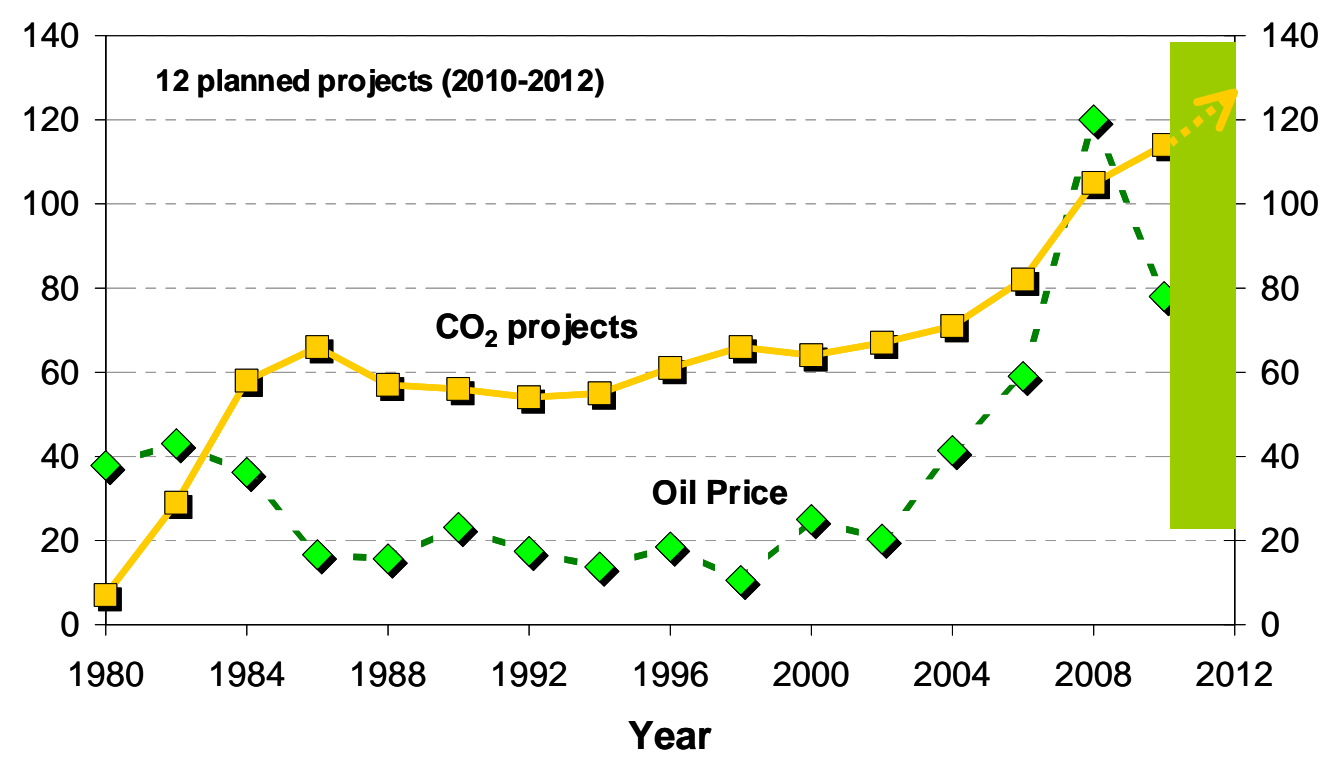

Although it can be concluded that $\mathrm{CO}_{2}$-EOR ("from natural sources") is a proven technology with oil prices $>\$ 20 / \mathrm{bbl}$, this EOR method represents a specific opportunity in the U.S. and not necessarily can be extrapolated to all producing basins in the world. Therefore, the present paper reviews worldwide EOR experiences considering the limitations of reservoir lithology, onshore vs. offshore opportunities, limitations of the existing infrastructure and access to injectants (e.g., $\mathrm{CO}_{2}$ ), market access and regional economic framework. Environmental aspects also play a more important role in the evaluation of the EOR strategies. This paper also describes $\mathrm{CO}_{2}$ EOR and/or Storage opportunities representing new EOR drivers and challenges, especially economics, at the same time. Recent EOR technology developments and future EOR opportunities will be also addressed.

\section{EOR by Lithology}

Reservoir lithology is one of the screening considerations for EOR methods, often limiting the applicability of specific EOR methods [23,24]. Figure 3 shows that most EOR applications have been in sandstone reservoirs, as derived from a collection of a 1,507 international EOR projects in a database consolidated by the authors during the last decade. From Figure 3, it is clear that EOR thermal and chemical projects are the most frequently used in sandstone reservoirs compared to other lithologies (e.g., carbonates and turbiditic formations). 
Figure 3. EOR methods by lithology (Based on a total of 1,507 projects).

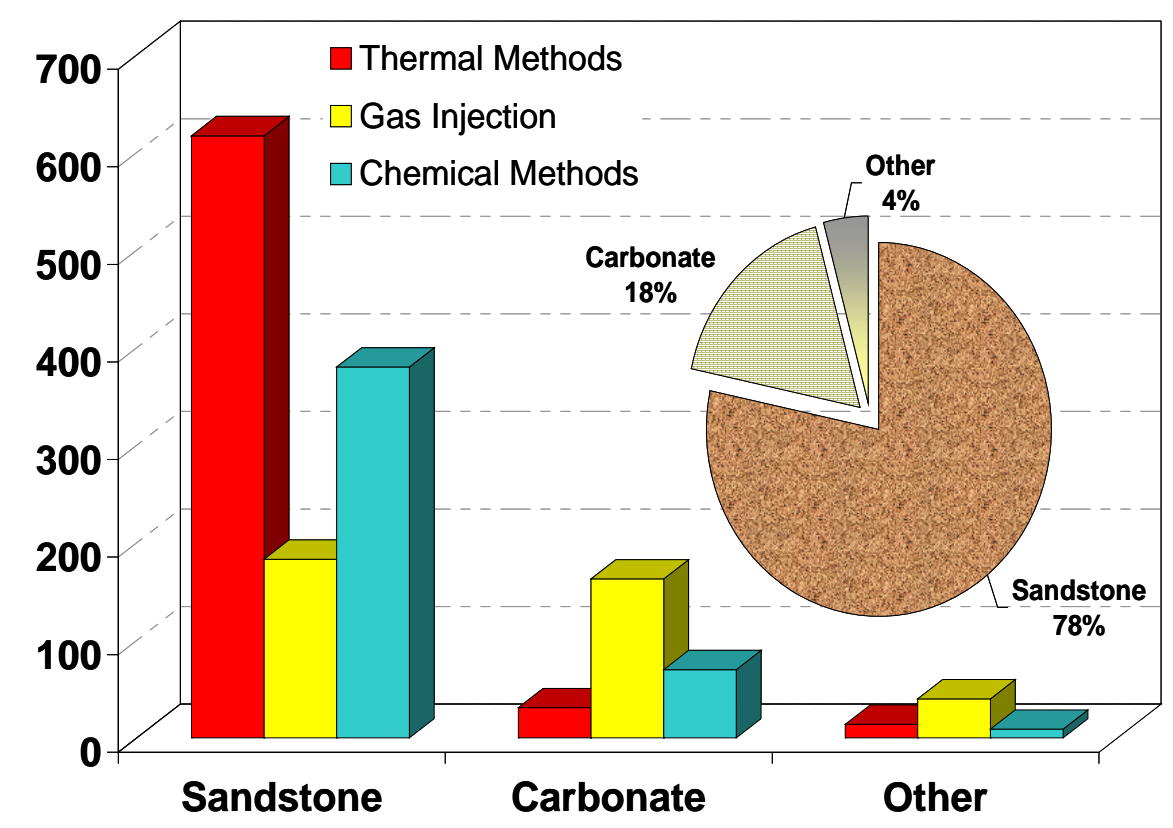

This section will describe the status, recent advances and future trends of EOR technologies based on reservoir lithologies.

\subsection{EOR in Sandstone Formations}

It is well known that EOR methods have been extensively implemented in sandstone formations. In general, sandstone reservoirs show the highest potential to implement EOR projects because most of the technologies have been tested at pilot and commercial scale in this type of lithology. Additionally, there are some fields where different EOR technologies have been evaluated successfully at pilot scale demonstrating technical applicability of different EOR methods in the same field. Buracica and Carmópolis (Brazil), and Karazhanbas (Kazakhstan) are good field examples that have been subject to several EOR technologies at pilot scale in sandstone formations:

- Buracica is an onshore light oil (35 $\left.{ }^{\circ} \mathrm{API}\right)$ reservoir with reported air injection (1978-1980), immiscible $\mathrm{CO}_{2}$ injection (1991) and polymer flooding (1997) pilot projects. Immiscible $\mathrm{CO}_{2}$ injection was expanded in the field using $\mathrm{CO}_{2}$ captured from an ammonia plant [25-30].

- Carmópolis is an onshore heavy oil (22 $\left.{ }^{\circ} \mathrm{API}\right)$ reservoir with reported in situ-combustion (1978-1989), polymer flooding (1969-1972 and 1997), steam injection (1978) and microbial EOR or MEOR (2002) pilot projects. The field has been developed mainly by waterflooding [27,31-34]).

- Karazhanbas is an onshore heavy oil (19 $\left.{ }^{\circ} \mathrm{API}\right)$ reservoir with documented polymer flooding [35], steam injection [36,37], in-situ combustion and in-situ combustion with foam injection as conformance strategy [37,38]). Karazhanbas Field was developed by waterflooding, CHOPS or Cold Heavy Oil Production with Sand [39] and steam injection. 
As was shown in Figure 3, thermal and chemical methods have been the EOR processes most widely applied in sandstone formations compared to EOR gas injection. The following section provides an overview of different EOR methods implemented in sandstone formations.

\subsubsection{Thermal Methods}

Cyclic steam injection (Huff \& Puff), steamflooding and most recently Steam-Assisted Gravity Drainage (SAGD) have been the most widely used recovery methods of heavy and extra-heavy oil production in sandstone reservoirs during last decades. Thermal EOR projects have been concentrated mostly in Canada, Former Soviet Union (FSU), U.S. and Venezuela, and Brazil and China to a lesser extent. Steam injection began approximately 5 decades ago. Mene Grande and Tia Juana field in Venezuela [40,41] and Yorba Linda and Kern River fields in California [42] are good examples of steam injection projects over four decades. Some examples of recent steam injection projects reported in the literature are the steamfloods in the Crude E Field in Trinidad [43], Schoonebeek oil field in Netherlands [44] and Alto do Rodrigues in Brazil [45]. Although attempts to optimize steam injection processes by using solvents [46], gases [47], chemical additives [48] and foams [49] have been proposed, few of these methods have been tested in the field $[38,50]$ ). One example is the LASER (for Liquid Addition to Steam for Enhancing Recovery) process, which consist in the injection of C5+ liquids as a steam additive in cyclic steam injection processes. Although the LASER process was tested at pilot scale in Cold Lake [51] the process has not been expanded at a commercial scale. Steam injection has also been tested in medium and light oil reservoirs being crude oil distillation and thermal expansion the main recovery mechanisms in these types of reservoirs [52]. However, steam injection in medium and light oil reservoirs has not contributed to EOR production worldwide.

Steam Assisted Gravity Drainage (SAGD) represents another important EOR thermal method to increase oil production in oil sands. Due to SAGD applicability in unconsolidated reservoirs with high vertical permeability [53], this EOR method has received attention in countries with heavy and extra-heavy oil resources, especially Canada and Venezuela, owning vast oil sands resources. However and despite SAGD pilot tests reported in China [54], U.S. [55] and Venezuela [56], commercial applications of this EOR process have been reported in Canada only and more specifically those implemented in McMurray Formation, Athabasca (e.g., Hanginstone, Foster Creek, Christina Lake and Firebag, among others). Figure 4 shows reservoir depths, average horizontal permeability and formation of several SAGD (pilot and large scale) projects well documented in the literature. Among these projects, only those developed in McMurray Formation (blue bars of Figure 4) operate commercially. SAGD projects tested in Clearwater formation in Cold Lake, Canada (yellow bars of Figure 4) have proved to be uneconomic [57]. Commercial SAGD projects in McMurray formation validate the importance of the geology and reservoir characteristics for this EOR method, findings that have been reported by Rottenfusser and Ranger [58], Putnam and Christensen [59], and Jimenez [60], among others. Therefore, the present level of understanding of the SAGD process and field experiences strongly suggest that this technology will continue to expand, depending of course on oil prices, mainly in Athabasca's McMurray formation. 
Figure 4. Depth, average permeability and formation of SAGD field projects.

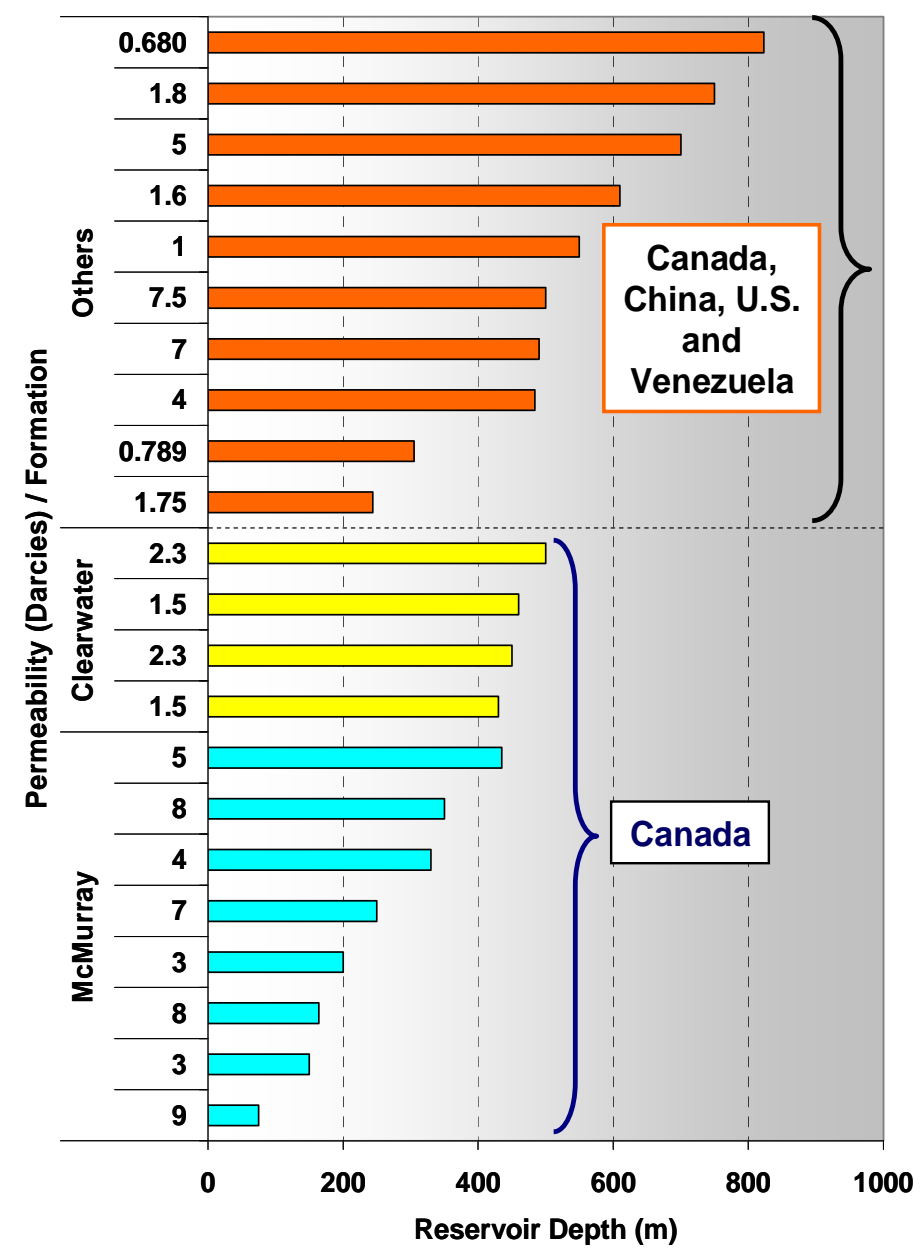

Alternatives to SAGD have been proposed. Those techniques include modified versions of SAGD through different well configurations or numbers of wells (e.g., Cross or X-SAGD, Fast SAGD and single well SAGD or SW-SAGD) or using additives (e.g., ES-SAGD) to steam [61-64]), respectively. However, all the proposed methods are at early stage of evaluation and are not expected to have an impact on oil production in the near future.

In-situ combustion (ISC) has been the second most important recovery method for heavy crude oils in the past decades. Despite its long history and some commercial successes, this EOR process has not been fully accepted among operators due to excessive number of inconclusive or failed pilots. However, an important number of failed projects can also be attributed to lack of understanding of the process and applications in reservoirs not necessarily appropriate for this EOR process. Although a few ongoing ISC projects in heavy oil reservoirs such as Battrum Field in Canada (Moritis [18]), Suplacu de Barcu, Romania [65,66]), Balol, Bechraji, Lanwa and Santhal in India [18,67-70] and Bellevue in the U.S. [18,71], air injection in light oil reservoirs (referred to as High Pressure Air Injection or HPAI) has gained greater attention during the last decade. The successful application of air injection projects in light oil reservoirs like West Hackberry in the U.S. demonstrate that this recovery process is a viable EOR strategy for high dipping angle reservoirs combined with Double Displacement (DDP) strategies [72,73]. Since year 2000, the number of ISC projects reported by Moritis [18] has been steady with 10 projects in sandstone formations. At the same time, the number of HPAI projects in 
U.S. light oil reservoirs has shown an important increase during the same period (Figure 5). However, all these HPAI projects have been implemented in carbonate formations and will be discussed later in the paper.

Figure 5. Trends in ISC and HPAI (From Moritis [18]).

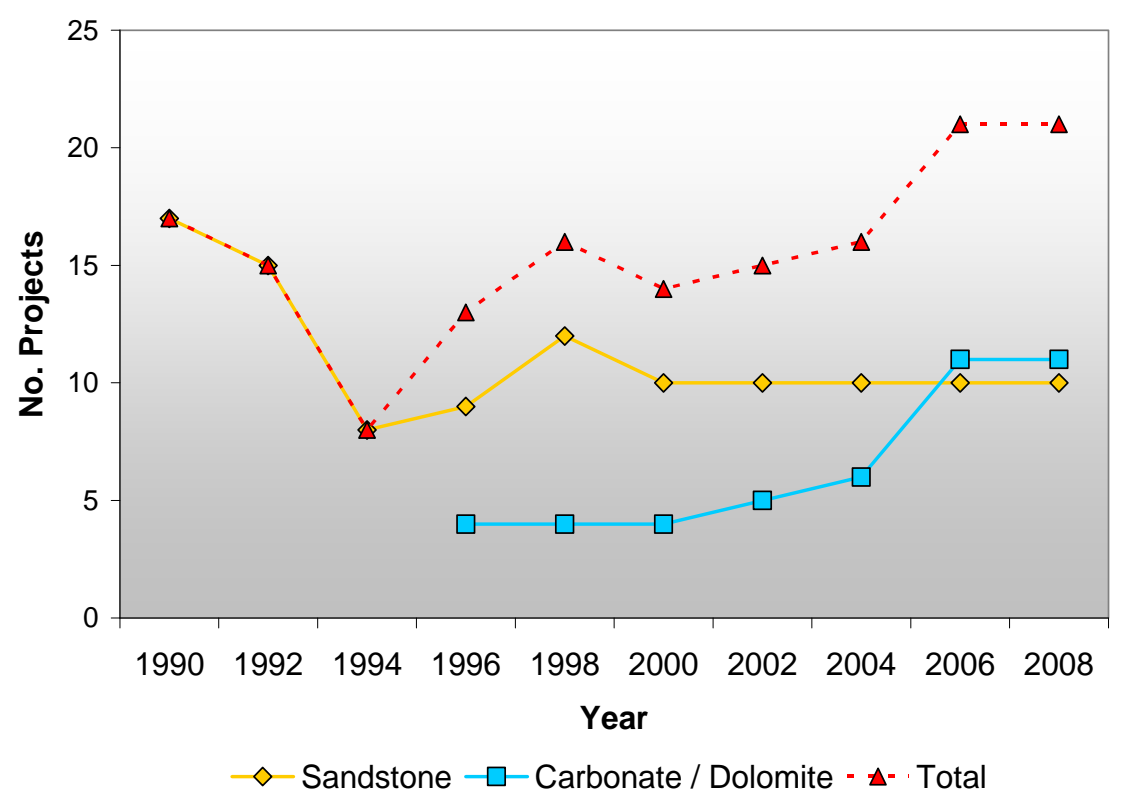

In addition to ISC and HPAI increasing trends reported by Moritis [18] during this decade, Duiveman et al. [74] and Hongmin et al. [75] documented air injection projects in Handil Field (2001), Indonesia and $\mathrm{Hu} 12$ Block, Zhong Yuan Field in China, respectively. Although Handil Field HPAI pilot $(0.5-1 \mathrm{cp}$ oil) reported injectivity problems due to lack of reservoir communication in the pilot area the results were reported as encouraging [74]. On the other hand, air injection pilot reported in Zhong Yuan Field (3.9 cp oil) consisted in a Foam Assisted Water-Alternating-Air Injection pilot also reporting encouraging results [75]. Other examples reflecting the growing interest in air injection are the planned ISC in Rio Preto West onshore Brazil reported by Moritis [18] and studies reported by Hughes and Sarma [76], Sarma and Das [77] and Teramoto at al. [78], and Onishi et al. [79] evaluating technical feasibilities and potential of HPAI in Australia and Japan, respectively. Based on these recent trends, we suggest that air injection, especially in light oil reservoirs (HPAI), will continue to grow in the next decade.

Alternatives to ISC such as the "Toe-to-Heel Air Injection" or THAI" [80,81] and CAPRI [82] processes have been proposed. CAPRI is the catalytic version of THAI (Catalytic THAI). Both processes are at early stages of evaluation through the Whitesands project partnership as reported by Petrobank Energy and Resources Ltd. [83]. Results of this project might be available by 2010 to confirm its EOR potential in oil sands and its potential applicability in other type of heavy oil reservoirs. Therefore, THAI is not expected to have an impact on EOR production in the near future. Additionally and as usual, crude oil price volatility will continue to play a key role to justify further THAI pilot tests. In regards to CAPRI processes, current competing surface upgrading technologies (e.g., SINCOR-Venezuela and Long Lake-Canada) may not justify the use of hydro-treating catalyst or costly hydrogen donors without having operational experiences with THAI. 
Finally, several other approaches of thermal EOR methods have been proposed with none or low impact on oil production. Some of them include downhole steam generation [84,85], electric heating [86-88] or electromagnetic heating [89,90] and microwave [91] technologies. However, these technologies have not been proved to be technically and economically feasible compared with traditional EOR thermal methods. Therefore, these technologies will not be further discussed in this paper.

\subsubsection{Chemical Methods}

Chemical EOR methods lived their best times in the 1980's, most of them in sandstone reservoirs [92]. The total of active projects peaked in 1986 with polymer flooding as the most important chemical EOR method (Figure 1). However, since 1990's, oil production from chemical EOR methods has been negligible around the world except for China [93-96]. Nevertheless, chemical flooding has been shown to be sensitive to volatility of oil markets despite recent advances (e.g., low surfactant concentrations) and lower costs of chemical additives.

Polymer flooding needs to be considered a mature technology and still the most important EOR chemical method in sandstone reservoirs based on the review of full-field case histories. It is important to remark that this paper does not consider near wellbore treatments (e.g., gels and polymer-gels) as EOR processes, leaving them out of the scope of this review. According to the EOR survey presented by Moritis in 2008 [18] there are ongoing pilots or large-scale polymer floods in Argentina (El Tordillo Field), Canada (Pelican Lake), China with approximately 20 projects (e.g., Daqing, Gudao, Gudong and Karamay fields, among others), India (Jhalora Field) and the U.S. (North Burbank, Oklahoma). It is important to mention that a commercial polymer flood was developed in North Burbank during the 1980s [97], demonstrating that this EOR method may still have potential to increase oil recovery in mature basins (i.e. mature floods with movable and/or by passed oil). North Burbank reinitiated polymer flooding on a 19-well pattern in December [98]. Other reported polymer flooding projects include Brazilian Carmópolis, Buracica and Canto do Amaro fields [26]. India also reports a polymer flood in Sanand Field [99,100]. Oman also documented a polymer flood pilot developed in Marmul Field [101] and almost twenty years later a large-scale application is under way [18]. Additionally, Argentina (El Tordillo Field), Brazil (Voador offshore Field), Canada (Horsefly Lake Field) and Germany (Bochstedt Field) announced plans to implement polymer flood projects [18]. Listed ongoing and planned polymer floods provide a representative sample of field experiences that validates EOR potential of this recovery process.

Colloidal Dispersion Gels (CDG's) and BrightWater ${ }^{\circledR}$ also represent novel polymer-based technologies that are currently under evaluation at field scale. Although these technologies are quite different from a technical standpoint, both are meant to improve volumetric sweep efficiency in mature waterfloods, especially in reservoirs with high permeability contrast and presence of thief zones. Documented CDG's projects include Daqing Field in China [96,102,103], El Tordillo [104] and Loma Alta Sur [105] fields in Argentina and in multiple U.S. oilfields [106,107]. Regarding BrightWater ${ }^{\circledR}$ [108], at the present time Milne Point in Alaska is the only field application discussed or documented in the public domain $[109,110]$. However, it is expected that the number of CDG's and BrightWater ${ }^{\circledR}$ 
field applications will increase in the near future based on recent field and laboratory studies underway, opening a new window of opportunities for EOR chemical methods [111-114].

While polymer flooding has been the most applied EOR chemical method in sandstone reservoirs [115], the injection of alkali, surfactant, alkali-polymer (AP), surfactant-polymer (SP) and Alkali-Surfactant-Polymer (ASP) have been tested in a limited number of fields (Figure 1). Micellar polymer flooding had been the second most used EOR chemical method in light and medium crude oil reservoirs until the early 1990's [116]. Although this recovery method was considered a promising EOR process since the 1970's, the high concentrations and cost of surfactants and co-surfactants, combined with the low oil prices during mid 1980's limited its use. The development of the ASP technology since mid 1980's and the development of the surfactant chemistry have brought up a renewed attention for chemical floods in recent years, especially to boost oil production in mature and waterflooded fields.

Several EOR chemical methods, other than polymer flood, have been extensively documented in the literature during the last two decades. However, at the present time Daqing Field represents one of the largest, if not the largest, ASP flood implemented as of today. ASP flooding has been studied and tested in Daqing for more than 15 years though several pilots of different scales [96,117-120]. Gudong [121], Karamay [122,123], Liahoe and Shengli [96] fields are other examples of Chinese ASP projects documented in the literature. Additional EOR chemical flooding reported during the last decade includes:

- ASP flooding in Viraj Field, India [124] and West Kiehl [125], Sho-Vel-Tum [126], Cambridge Minnelusa [127] and Tanner [128] fields in the U.S.

- AP flooding in Xing Long Tai Oil Field [129] in China and David Pool in Canada [130].

According to the EOR survey presented by Moritis in 2008 [18] there are ongoing ASP pilots in Delaware Childers Field (Oklahoma) and also refers to planned ASP floods in Lawrence Field (Illinois) and Nowata Field (Oklahoma), and SP floods in Midland Farm Unit, Texas (Grayburg Carbonate Fm.) and in Minas Field, Indonesia [131]. However, the number of ASP and SP floods is much higher than the ones reported in the literature as well the EOR survey presented by Moritis [18] because operators not necessarily respond to this survey. Authors of this paper are aware of ongoing projects in the U.S. and Canada not published in the literature [132]. Additionally, there are several projects in Argentina, Canada, India and the U.S. under reservoir and lab evaluations with pilot projects scheduled between 2010 and 2011. Therefore and despite the volatility of oil prices, it is fair to conclude that operators and surfactant manufacturers are showing a growing interest in EOR chemical flooding [132,133]. This trend is also noticed with an increase of screening and lab studies to evaluate or re-estimate EOR potential of chemical flooding in different basins [134-141].

\subsubsection{Gas Methods}

EOR gas flooding has been the most widely used recovery methods of light, condensate and volatile oil reservoirs. Although nitrogen $\left(\mathrm{N}_{2}\right)$ injection has been proposed to increase oil recoveries under miscible conditions favoring the vaporization of light fractions of light oils and condensates, today few $\mathrm{N}_{2}$ floods are ongoing in sandstone reservoirs. Immiscible $\mathrm{N}_{2}$ floods are reported in Hawkins Field (Texas) and Elk Hills (California) based on the Moritis EOR survey in 2008 [18]. No new $\mathrm{N}_{2}$ floods in 
sandstone reservoirs have been documented in the literature during the last few years and we do not foresee an increment in the number of projects implementing this EOR gas flooding method.

Similarly to $\mathrm{N}_{2}$ injection, hydrocarbon gas injection projects in onshore sandstone reservoirs have made a relatively marginal contribution in terms of total oil recovered in Canada and the U.S. other than on the North Slope of Alaska, where large natural gas resources are available for use that do not have a transportation system to markets. It is important to mention that in this paper we refer to EOR gas methods using hydrocarbon gases such as Water-Alternating-Gas (WAG) injection schemes, enriched gases or solvents and its combinations. Therefore, hydrocarbon gas injection as pressure maintenance or double displacement strategies are not considered EOR methods for purposes of this review. Most of immiscible and miscible EOR hydrocarbon gas floods in the U.S. are on the North Slope of Alaska [18,142-145] while in Canada a miscible gas flood is reported in Brassey Field [18]. The situation of hydrocarbon gas injection projects is different in offshore sandstone reservoirs [146]. However, this will be addressed later in the paper. In general, if there is no other way to monetize natural gas, then a more practical use of natural gas would be to use it in pressure maintenance projects or in WAG processes. However and if available, the substitution of hydrocarbon gases by non-hydrocarbon gases $\left(\mathrm{N}_{2}, \mathrm{CO}_{2}\right.$, acid gas, air) oil recovery will make more natural gas available for domestic use or export while still maintaining reservoir pressure and increasing oil recoveries. Despite current low natural gas prices, the continued increase in energy demand will likely affect the viability of new large-scale hydrocarbon gas projects.

On the other hand, $\mathrm{CO}_{2}$ flooding has been the most widely used EOR recovery method for medium and light oil production in sandstone reservoirs during last decades, especially in the U.S. due to the availability of cheap and readily available $\mathrm{CO}_{2}$ from natural sources. Figure 2 clearly shows an increasing trend in the number of $\mathrm{CO}_{2}$ field projects in the U.S during the last decade in both, sandstone and carbonate reservoirs. The number of $\mathrm{CO}_{2}$ floods is expected to continue to grow in U.S. sandstone reservoirs. Some examples of planned $\mathrm{CO}_{2}$-EOR projects in the U.S. include Cranfield Field, Heidelberg West (from anthropogenic sources) and Lazy Creek Field in Mississippi and Sussex Field in Wyoming [18]. Number of $\mathrm{CO}_{2}$ floods in Wyoming sandstone reservoirs are also expected to increase based in a recent evaluation presented by Wo et al. [147] (this will be constrained by availability of $\mathrm{CO}_{2}$ for injection). Additionally, Holtz [148] recently reported an overview of sandstone gulf coast and Louisiana $\mathrm{CO}_{2}$-EOR projects to estimate EOR reserve growth potential in the area including sandstone reservoirs in the Gulf of Mexico. $\mathrm{CO}_{2}$-EOR in the U.S. has shown a vast potential to increase oil recovery and has been widely documented in the literature. Therefore, the present review will address briefly activities reported outside the U.S.

Some examples of $\mathrm{CO}_{2}$-EOR field projects in sandstone formations presented in various conferences and/or documented in the literature are summarized below:

- Brazil reports $\mathrm{CO}_{2}$ floods in Buracica and Rio Pojuca fields [18,149] and announced a $\mathrm{CO}_{2}$ flood in Miranga Field from anthropogenic sources as an EOR and carbon storage strategy $[149,150]$.

- Canada actually reports $\mathrm{CO}_{2}$ floods in Joffre and Pembina fields [18,151]. Operators and government institutions of Canada have been very active evaluating $\mathrm{CO}_{2}$-EOR potential during the last decade [152,153]. Recently PTAC (Petroleum Technology Alliance of Canada) 
estimated an up-side potential of $\mathrm{CO}_{2}$-EOR in Alberta of 3.6 billion barrels over the next two decades at oil prices of $\$ 45 / \mathrm{bbl}[154]$.

- Croatia reported a $\mathrm{CO}_{2}$ pilot injection at Ivanić Field injecting $\mathrm{CO}_{2}$ transported by trucks. Pilot results (2001-2006) contributed to define larger application of $\mathrm{CO}_{2}$-EOR in the country considering the use of $\mathrm{CO}_{2}$ from anthropogenic sources [155-157]).

- Hungary also reports more than four decades experience in $\mathrm{CO}_{2}$-EOR floods. $\mathrm{CO}_{2}$ projects at Budafa and Lovvaszi fields are two cases well documented in the literature [158]. Szank Field represents a more recent $\mathrm{CO}_{2}$-EOR flood in Hungary using $\mathrm{CO}_{2}$ from a sweetening plant [160].

- Trinidad also has more than three decades experience operating $\mathrm{CO}_{2}-\mathrm{EOR}$ projects using $\mathrm{CO}_{2}$ an ammonia plant nearby the fields [161]. Moritis EOR survey [18] reports up to nine (9) active immiscible $\mathrm{CO}_{2}$ floods operating since mid 1970s.

As can be seen, $\mathrm{CO}_{2}$-EOR has become one of the preferred EOR processes globally and considering $\mathrm{CO}_{2}$ from natural and industrial sources. Mexico (Muro et al. [161] and the U.S. [147,163] are just few examples of countries evaluating $\mathrm{CO}_{2}$ sources and EOR potential in mature fields and mature $\mathrm{CO}_{2}$ floods [164]. However, this will be further discusses in the section of EOR gas methods in carbonate formations.

\subsection{EOR in Carbonate Formations}

It is well known that a considerable portion of the world's hydrocarbon endowment is in carbonate reservoirs. Carbonate reservoirs usually exhibit low porosity and may be fractured. These two characteristics along with oil-to-mixed wet rock properties usually result in lowered hydrocarbon recovery rates. When EOR strategies are pursued, the injected fluids will likely flow through the fracture network and bypass the oil in the rock matrix. The high permeability in the fracture network and the low equivalent porous volume frequently results in early breakthrough of the injected fluids.

A large number of EOR field projects in carbonate reservoirs have been referenced in the literature during the last decades. Although these field projects demonstrate the technical feasibility of various EOR methods in carbonate reservoirs, gas injection (continuous or in a WAG mode) are still the most common EOR process implemented in this type of lithology (Figure 3). Polymer flooding is the only proven EOR chemical method in carbonate formations while EOR thermal methods have made a relatively small contribution to world's oil production from carbonate reservoirs. However, High Pressure Air Injection (HPAI) projects have been steadily increasing in recent years, especially in light oil carbonate reservoirs in the U.S. [165].

In contrast with sandstone reservoirs, there are few fields where different EOR technologies have been evaluated successfully at pilot scale demonstrating technical applicability of different EOR methods in carbonate formations. Yates Field (Texas) is a good example of a carbonate formation where different EOR processes have been tested successfully at different scales (from pilots to large scale applications). Some of the EOR processes evaluated in Yates Field that have been documented in the literature include:

- Nitrogen $\left(\mathrm{N}_{2}\right)$ injection began in the mid 1980's as a reservoir pressure maintenance strategy [166-168]. 
- Steam flooding pilot was initiated late 1998 as a potential strategy to improve vertical gravity drainage process (Button and Peterson [168-170].

- Dilute surfactant well stimulation pilot test was reported early 1990's as a strategy to increase oil recovery by IFT reduction, gravity segregation of oil and wettability alteration, among others mechanisms [19,168,171-174].

- In March 2004 Yates Field started replacing $\mathrm{N}_{2}$ injection with $\mathrm{CO}_{2}$ injection as a pressure maintenance strategy and enhanced gravity drainage [168].

Manrique et al. [19] presented a comprehensive review of EOR field experiences in U.S. carbonate reservoirs. Although this review was specific for U.S. carbonate formations, it can be considered representative to estimate technical feasibility and potential of EOR processes in this type of reservoirs based on valuable field experiences documented in the literature. Alvarez et al. [175] recently documented a literature review of field experiences specifically in heavy oil carbonate reservoirs including several pilot tests carried out in the Grosmont formation in Canada during 1970's and 1980's (e.g., Chipewyan River, Buffalo Creek, McLean, Orchid, Saleski and Algar). Therefore, the following section provides a general overview of different EOR methods implemented in carbonate formations around the world complimenting recent review's documented in the literature.

\subsubsection{Thermal Methods}

Thermal EOR projects have not been popular in carbonate formations. Neither cyclic nor continuous steam injection has been widely used in carbonate reservoirs. The Garland Field in Wyoming [169] and Yates Field in Texas [168] represent two of the few steam drive projects in carbonate formations documented in the U.S [19]. Some of the steam injection projects documented in carbonate formations outside Canada and the U.S. includes:

- Steam drive pilot at Lacq Supérieur Field, France [176,177].

- Steamflood Pilot at Ikiztepe Field, heavy oil fracture reservoir in Turkey [178].

- Cyclic steam pilot in Cao-32 Field, fracture limestone heavy crude oil in China [179].

- Steamflood pilot and recently announced full field implementation in Qarn Alam Field, Oman [18,180-182]. Oman also announced steam injection project in limestone Fahud Field among other steam pilots [18].

- Cyclic steam injection pilot in Issaran heavy oil field, Egypt [183].

- Steamflood pilot at the giant Wafra Field, Kuwait—Saudi Arabia [184,185].

As can be seen, steam injection in carbonates has been mostly tested at small scale and only Qarn Alam Field in Oman is announcing full field steam flooding operations. Therefore, steam injection in Qarn Alam Field will contribute to define the future of steam injection in carbonate formations. SAGD is another technology that has been proposed for carbonate reservoirs [186,187]. A very limited number of studies are considering this recovery process for fractured carbonate reservoirs. However, the authors of this article believe the fractured and vuggy nature of carbonate formations can cause uneven sweeping along SAGD well pairs. This may lead to irregular steam chambers development causing the early breakthrough of steam into the horizontal producer, resulting in low recovery factors, and therefore uneconomic projects. 
On the other hand, air injection projects in carbonate formations have shown a steady increase since 2000, especially HPAI projects in U.S. light oil reservoirs (Figure 5). To date, U.S. operates eleven (11) HPAI projects in light oil ( $>30^{\circ}$ API) carbonate reservoirs in Montana and in North and South Dakota [18]. South and West Buffalo, and Medicine Pole Hill are good examples of combustion projects in light crude oil dolomitic formations [19]. The Buffalo Field (North Dakota) started air injection approximately 3 decades ago and projects are still in operation [188,189]. The success and expansion of Buffalo and Medicine Pole Hill in North and South Dakota have contributed with the increase of HPAI projects in the area. Although all HPAI reported by Moritis [18] in Montana, North and South Dakota have been developed in the same low permeable dolomitic formation (Red River A, $\mathrm{B}$ and/or C), air injection have proven to have high potential to improve oil recovery and revitalize both mature and waterflooded carbonate reservoirs [190,191]. This will be especially true in fields located in remote locations with no access to $\mathrm{CO}_{2}$ sources.

There is no doubt that risk perception of air injection processes is still part of our industry. However, actual HPAI projects in U.S. carbonate reservoirs demonstrate that risks can be controlled and this process is economically attractive. Mexico is one example of countries evaluating air injection processes in naturally fractured carbonates given that most of its production and reserves are coming from this type of reservoirs. Mexico announced a potential HPAI project in The Cárdenas Field, onshore light oil (40 ${ }^{\circ}$ API) fractured carbonate reservoir located in the South Region of the Chiapas-Tabasco basin [192]. Therefore, production results from recent air injection projects in the U.S. (Williston Basin) and potentially the pilot project in Cárdenas Field (Mexico) are likely to dictate the future of this recovery method in carbonate reservoirs in the U.S. and abroad.

\subsubsection{Chemical Methods}

Polymer flooding is the only proven chemical EOR technology, mostly at early stages of waterflooding, in carbonate reservoirs (Figure 3). However, carbonate reservoirs have made a relatively small contribution to polymer flooding in terms of total oil recovered in the U.S. [19]. With today's technology, Alkali-Polymer (AP) and Alkali-Surfactant-Polymer (ASP) floods are applicable to sandstone reservoirs only. However, surfactant-polymer (SP) seems to be a feasible recovery process in both carbonate (e.g., Midland Farm Unit, Texas) and sandstone reservoirs. As of date, no chemical flooding other than polymer-flooding field in carbonate reservoirs have been reported in the literature reviewed. However, ASP has been tested in carbonate formations in the lab in Arab-D [193] and Upper Edward's [19] and Pietra Leccese outcrop [194-196] in core samples. Alkali-Surfactant single well test has been reported in the Mauddud carbonate reservoir in Bahrain as part of ASP feasibility studies in oil-wet limestone reservoirs [197].

Surfactant injection is the only chemical method used recently as a well stimulation and wettability modification of carbonate reservoirs. In fractured reservoirs, spontaneous water imbibitions can occur from the rock matrix into fractures. Subsequently, this mechanism leads to oil drainage from the matrix towards the fracture network, making surfactants attractive to improve oil recovery in oil-wet carbonate reservoirs by changing rock wettability (to mixed/water wet) and promoting the imbibition process. Cottonwood Creek and Yates fields are two examples of surfactant stimulations well documented in the literature. Recent studies in Norway have demonstrated positive effect of seawater 
injection in the carbonate chalk reservoirs, when sulfate-containing seawater contributed to the development of strong water wettability of the chalk matrix rock over the years of waterflooding [19]. Given the vast quantity of world's oil reserves is contained in carbonate reservoirs, chemically-assisted methods (e.g., spontaneous imbibition, wettability modifiers and ITF reductions) based on surfactant injection represents an active research area as a strategy to improve oil recovery in carbonate formation [198-204]. However, as of today no large field application has been documented in the open literature.

Based on the present status of the technology, chemical EOR methods are not expected to make an important contribution in oil production from carbonate reservoirs during the next one or two decades. However, chemically based gas and water shut-off strategies (e.g., gels and foams) will continue to contribute optimizing water, gas or WAG projects in carbonate reservoirs in the near future [205-211].

\subsubsection{Gas Methods}

EOR gas flooding has been the most widely used recovery methods of light, condensate and volatile oil carbonate reservoirs. Figure 3 clearly shows that gas injection have been the EOR method most frequently applied in carbonate formations compared to EOR chemical and thermal methods.

$\mathrm{N}_{2}$ flooding has been an effective recovery process for deep, high-pressure, and light oil reservoirs. Generally for these types of reservoirs, $\mathrm{N}_{2}$ flooding can reach miscible conditions. However, immiscible $\mathrm{N}_{2}$ injection has also been used for pressure maintenance, cycling of condensate reservoirs, and as a drive gas for miscible slugs [19]. Although over the last four decades several $\mathrm{N}_{2}$ injection projects have been reported in carbonate reservoir in the U.S., Moritis [18] reports only one miscible WAG-N $\mathrm{N}_{2}$ in Jay LEC a deep (15,400 ft) carbonate reservoir in Florida and Alabama [212]. However, more recently, the operator of that field announced a temporary production suspension at the Jay Field [213]. Outside the U.S., Cantarell is the only representative $\mathrm{N}_{2}$ injection project ongoing in an offshore carbonate field well documented in the literature [214]. No new $\mathrm{N}_{2}$ floods in carbonate reservoirs have been documented in the literature during the last few years and we do not foresee an increment in the number of projects implementing this EOR gas flooding method, but in Campeche Bay Area in the Gulf of Mexico (GOM) in Mexico. The number of projects in this area (e.g., KMZ) is expected to grow in the near future given the availability of $\mathrm{N}_{2}$ generation capabilities in the region. High capital (e.g., Air separation units) and operational (e.g., $\mathrm{N}_{2}$ rejection units, if required) costs associated to $\mathrm{N}_{2}$ injection have reduced the interest in this recovery process in recent years. Additionally, with recent successes and field expansions reported in Montana, North Dakota and South Dakota HPAI (High Pressure Air Injection) has surged as a potential option with lower capital and operational costs than miscible $\mathrm{N}_{2}$ floods. However, $\mathrm{N}_{2}$ injection still represents an option that can be justified for high pressure and high temperature (HP/HT) light oil reservoir if there is no access to other gas sources [215,216].

Similar to $\mathrm{N}_{2}$ injection, hydrocarbon gas injection projects in onshore carbonate reservoirs have made a relatively marginal contribution in terms of total oil recovered in Canada and the U.S. $[18,19]$. As was aforementioned, in this article we refer to EOR gas methods using hydrocarbon gases Water-Alternating-Gas (WAG) injection schemes, enriched gases or solvents and its combinations (Hydrocarbon miscible flooding) [217]. Some examples of the hydrocarbon miscible flooding (continuous injection or in WAG mode) ongoing or under evaluation in carbonate formations that have been documented are reported in Canada, the Middle East and offshore carbonate formations 
[18,218-223]. If there is no other way to monetize natural gas, then a more practical use of natural gas would be to use it in pressure maintenance projects or in WAG processes while new business opportunities become available. This development strategy will contribute to preserve reservoir energy maximizing oil recovery with an upside potential of monetizing natural gas through reservoir depressurization strategies implemented or proposed in the North Sea [224-226].

$\mathrm{CO}_{2}$-EOR has been successfully implemented in both mature and waterflooded carbonate reservoirs $[18,19] . \mathrm{CO}_{2}$ flooding from natural sources has been the most important EOR process in the U.S. and particularly in carbonate reservoirs of the Permian Basin. Moritis [18] reported 105 active $\mathrm{CO}_{2}$ floods in the U.S. being 63 projects in carbonate formations mainly in the Permian basin of Texas. The popularity of $\mathrm{CO}_{2}$ projects is closely related to the abundant availability of natural sources of $\mathrm{CO}_{2}$ and associated $\mathrm{CO}_{2}$ transporting pipelines that are generally located close to the oilfields [19,21]. $\mathrm{CO}_{2}$-EOR in U.S. carbonate reservoirs is expected to continue to grow (Figure 2) based on natural sources of $\mathrm{CO}_{2}$. If $\mathrm{CO}_{2}$ flooding is to increase, non-natural sources will need to be incorporated at competitive costs. In simple terms, if $\mathrm{CO}_{2}$ is available it will remain the most sound recovery choice for carbonate reservoirs unless more viable EOR strategies are developed. Canada (e.g., Enchant Midale, Judy Creek, Swan Hills and Weyburn) and Turkey (e.g., Bati Raman) also report well documented $\mathrm{CO}_{2}$-EOR projects in carbonate formations [18,227-230]. It is important to remark that Weyburn represents a large $\mathrm{CO}_{2}$-EOR project based on anthropogenic sources (Coal gasification) of $\mathrm{CO}_{2}$. Finally and most recently, Saudi Aramco announced its plans to inject $\mathrm{CO}_{2}$ as an EOR and storage strategy at the giant Ghawar field. This strategy not only will contribute to reduce emissions but will also increase natural gas availability for power generation [231,232].

In today's world addressing $\mathrm{CO}_{2}$-EOR projects almost always inevitably links these projects to topics such as climate change. Climate change has become an issue of intense discussion over the last decade. Despite strong debate within the scientific community as to whether or not global warming is linked to population growth and industrial development, the international community is proactively trying to secure resources to meet future energy demands while simultaneously restricting $\mathrm{CO}_{2}$ and other greenhouse gas emissions generated by current energy production [233]. This topic has been overwhelmingly documented in the literature. Thus, this review will not try to provide an extensive list of references related to this topic. What the authors are trying to highlight is that $\mathrm{CO}_{2}$-EOR has become an attractive $\mathrm{CO}_{2}$ storage alternative among the options currently available. However, it is important to remind that $\mathrm{CO}_{2}$ storage capacity in oil and gas reservoirs is limited [166,234-236].

The fundamental reason why $\mathrm{CO}_{2}$ storage combined with EOR has become the preferred emission reduction strategy is because high hydrocarbon price scenarios provide the necessary financial incentive for increasing oil and gas reserves through EOR methods and also generates the capital needed to fund such projects until proper regulatory framework is in place [237-241]. $\mathrm{CO}_{2}$-EOR is a proven technology that certainly can offset, if not exceed, the costs of $\mathrm{CO}_{2}$ capture, transportation, and injection of $\mathrm{CO}_{2}$ storage projects. However, based on actual cost of $\mathrm{CO}_{2}$ capture, compression and transportation (if pipelines are not readily available) costs will be too high making $\mathrm{CO}_{2}$-EOR economically unattractive. Adding the lack of proper regulatory framework among other soft issues (e.g., public perception), we do not foresee an important increase in the number of projects implementing $\mathrm{CO}_{2}$-EOR from anthropogenic sources in the near future. In summary, the basic requirements to consider $\mathrm{EOR}$ a $\mathrm{CO}_{2}$ (or greenhouse gases) storage have not been well established as 
of yet, which makes monitoring costs for potential leakage, i.e. liability issues, unattractive to oil companies based on lifecycle analysis. Therefore, potential drivers of $\mathrm{CO}_{2}$-EOR and storage will come from federal funding (e.g., DOE), utility and industry incentives for costly technology development, and changes in climate legislation or environmental regulations.

The economics (costs and revenues) involved in a CCS project can be broken down in many ways. However, it depends on the source of $\mathrm{CO}_{2}$ (e.g., petrochemical plants vs. coal-fired power plants) and where it will be injected (e.g., EOR vs. saline aquifer). Assuming a scenario of $\mathrm{CO}_{2}$ capture from a coal-fired power plant, we can divide the main economic variables into four categories: $\mathrm{CO}_{2}$ capture and compression, $\mathrm{CO}_{2}$ transportation, $\mathrm{CO}_{2}$ storage (including wells and monitoring), and possible revenues (e.g., oil recovery and/or carbon credits), depending on the application $\left(\mathrm{CO}_{2}\right.$-EOR vs. saline aquifers). Figure 6 shows an example of the main costs and revenues associated with $\mathrm{CO}_{2}$-EOR storage. Cost shown in Figure 6 represents average costs obtained from a comprehensive (unpublished) literature review completed in 2008. However, it is important to recall that costs such as transportation and compression of $\mathrm{CO}_{2}$ will vary depending on the distance between the emission source (e.g., power plant) to the geologic sink (e.g., oil reservoir or saline aquifer) and its depth. Oil, carbon credits, and rates of exchange were obtained from different Internet sources [242-244]).

Figure 6. Example of total costs and potential incomes of carbon capture storage projects with EOR $\left(\mathrm{CO}_{2}\right.$-EOR storage).

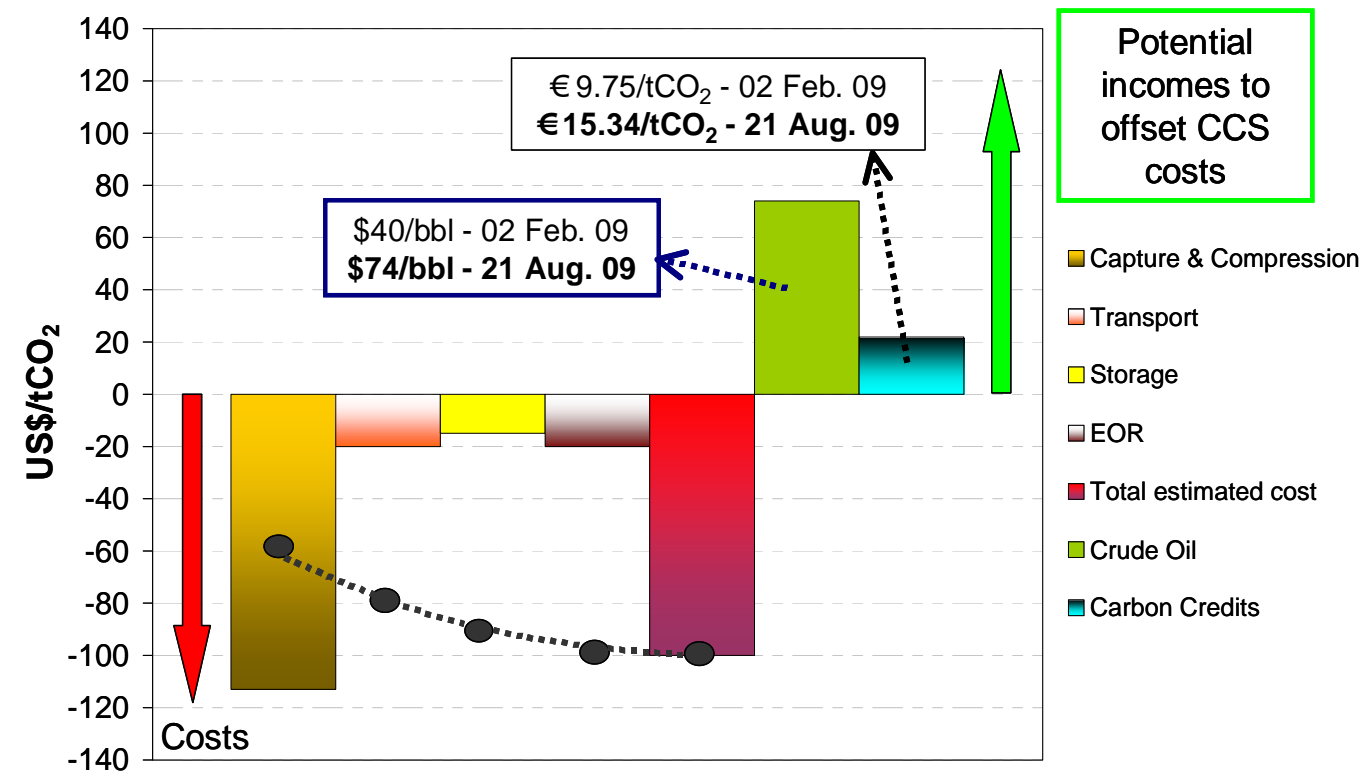

Regarding the carbon credits, the use of EUA OTC (European Union Allowances-Over the Counter Market) was arbitrarily selected because of easy access and the possibility of tracking historic prices as well as market definitions [245]. From Figure 6, an approximate cost of US\$100 per ton of $\mathrm{CO}_{2}$ was estimated based on our reviews (total estimated cost per ton of $\mathrm{CO}_{2}$ captured and stored), while the estimated incomes (oil prices and carbon credits) show their volatility in two, randomly selected, months of 2009. For the carbon credits, a rate of exchange of US\$1.43 per euro was used [244]. It is important to mention that in April 2008, the average oil price was US\$119/bbl and EUA OTC was reported to be at US\$38.05/ $\mathrm{tCO}_{2}$ [236]. Therefore, combining price volatility of oil prices and carbon 
credits with costs associated with $\mathrm{CO}_{2}$ capture, compression, and transportation (if pipelines are not readily available), $\mathrm{CO}_{2}$-EOR and storage might not be economically feasible unless additional incentives are established.

On the other hand, carbon credits will definitively not offset costs associated with CCS in saline aquifers (without EOR), at least in the near future (Figure 6). Additionally, the cost of $\mathrm{CO}_{2}$ storage (including monitoring) in saline aquifers might be too high because of the lack of reservoir characterization and existing infrastructure (wells and surface facilities) compared to oilfields. As shown in Figure 6, $\mathrm{CO}_{2}$ capture and compression represent capital-intensive phases of any CCS project. Therefore, it is believed that with the refinement of current capture technologies and/or the development of new technologies, the opportunity will exist for major cost reductions in CCS projects. $\mathrm{CO}_{2}$ capture costs around or below $\$ 30 /$ ton are considered necessary in order to justify the economic feasibility of CCS projects in the near term, assuming that the proper regulatory environment and carbon market framework, among other issues (e.g., public perception) are in place. Therefore, we do not foresee an important increase in the number of projects implementing $\mathrm{CO}_{2}$-EOR from anthropogenic sources in the near future.

Finally, acid gas (mixtures of $\mathrm{H}_{2} \mathrm{~S}$ and $\mathrm{CO}_{2}$ ) injection has been also reported as an injectant for EOR applications in carbonate formations [18]. Zama Field in Canada [246], Tengiz Field in Kazakhstan [247] and Harweel Cluster in Oman (O'Dell et al., [248]) are a few examples of carbonate reservoirs with ongoing or planned sour or acid gas injection as EOR strategies.

\subsection{EOR in Turbiditic Formations}

Turbidite reservoirs are not a separate litho type, since they are sandstone formations. These deposits occur as a result of underwater landslides that create the so-called turbidity currents. As a result, they are frequently encountered in offshore locations such as Angola, Brazil and Gulf of Mexico. Our choice to present this particular type of reservoir is due to their importance in offshore environments and as target for important EOR applications [249]. Morel et al. [249] carried out a detailed feasibility study for an offshore reservoir with good petrophysical properties, which is also typical of other turbiditic reservoirs, but not always. As the authors indicate, this type of reservoirs provides good conditions for polymer injection, such as low temperature and relatively viscous oil at reservoir conditions, but severe shortage of platform space represents a problem. We summarize conditions of turbiditic environments with particular emphasis in the Brazilian offshore.

\subsubsection{Brazil Offshore}

Brazil represents a steadily growing oil and gas province in the Atlantic. Brazilian oil production represents an example of two very contrasting scenarios, one for onshore fields, with most of the reservoirs in an advance state of maturity, as opposed to offshore fields, most of them more recent discoveries, several of them early or midway in their production life. Some challenging situations are associated with the latter as shall be seen in this summary.

Shecaira et al. [26] summarize the IOR evolution in Brazil and its outlook, most of all after the creation of Petrobras, the stated-owned oil company, in 1953. IOR efforts in Brazil began in the sixties with water flooding in onshore fields, and subsequently with the use of several tertiary methods. The 
gradual increase in oil production from offshore areas in the late seventies changed the IOR panorama for Brazil. At present, water injection represents the main IOR activity in offshore fields, which accounts for roughly $74 \%$ of the Brazilian daily oil output.

Although Brazil experimented with several of the tertiary recovery alternatives proposed internationally, only a few methods actually moved from pilot evaluation to field scale. Commercial EOR in Brazil includes steam injection, carbon dioxide and polymer flooding. All these projects were executed on onshore fields, all of them in sandstone reservoirs, many in good quality reservoirs (see summary in Table 1, Appendix). It should be noticed that many of the projects were implemented between 1969 and 1985, time period that preceded the fall of oil prices with the known effects on EOR activities at the time worldwide, including Brazil.

The situation in offshore fields represents a different and very challenging situation. Major offshore discoveries concentrate at water depths beyond 1,200 $\mathrm{m}(3,936 \mathrm{ft})$. The latter, of course, narrows down the number of possible IOR alternatives, mainly focusing on reservoir management optimization choices, combined with well architectures such as horizontal or highly deviated wells to yield maximum return from those fields. Since waterflooding is the main offshore activity in Brazil, water management becomes an important issue. By 2002, twelve fields were under water injection, mainly for pressure maintenance, while for other seven, water injection plans were underway. From the 888,000 bwpd injected by 2005, and 330,000 bwpd produced, it was expected that roughly 3,145,000 bwpd will be injected by 2006. Several problems are associated with water injection. Lost of injectivity is an impairing problem because of the subsea wells completions that tend to dominate production schemes in the Brazilian offshore. Intervention for stimulation purposes in injection wells becomes rather expensive, requiring floating rigs. Several alternatives to alleviate water management problems have arisen. Open-hole completion in water injectors has been successful, but remedial activities for water diversion are then difficult. Raw water injection (or lower quality water) above the fracture threshold has been put forth as a serious option, and Petrobras PRAVAP program has dedicated efforts in this direction (PRAVAP is Petrobras corporative technology program that covers all aspects of the EOR activity, including monitoring programs such as time-lapse seismic). Another issue, now for producer wells, is inorganic salt deposition, mainly Barium and Strontium sulfates.

Offshore heavy oil reservoirs (API gravity lower than 19 and/or oil viscosity greater than $10 \mathrm{cp}$ at reservoir conditions) are a challenge for operators in Brazil. The current proposed alternative would be cold production through high productivity wells (long-reach extended horizontal wells), plus associated water injection. Well-planned well architectures to delay/minimize water production and increase sweep efficiency are being proposed to make exploitation feasible. However, no more than $20 \%$ recovery factor is expected at present. A number of emblematic offshore oil fields are summarized in this section.

Albacora [250-253], one of the offshore giant fields, contains an estimated STOIIP of 4.4 billion bbl (by 1989, time of the development plan) at water depths ranging from $230 \mathrm{~m}$ up to $1,900 \mathrm{~m}$. The field was expected to develop in 3 phases for a peak production of 288,000 bopd from 188 completed wells. The idea being to prepare exploitation phases for successively deeper water, as technology development and learning curves required progressed. This is tendency in offshore operations in the Campos basin, because water depths grow substantially reaching ultradeep waters in some of the new discoveries. 
Seven oil reservoirs were detected: Namorado (typical cretaceous turbiditic sandstone in Campos basin), and Eocene, Oligocene 1, Oligocene 2, Oligocene 3, Oligo-Miocene and Miocene, Tertiary. Namorado is a representative turbidite in the Brazilian offshore, like Brent for the North Sea, present in many of the Campos Basin reservoirs. At the time (1989), the field represented $10 \%$ of Brazilian STOOIP and $15 \%$ of Campos basin STOOIP.

Phase I comprised the production of six exploratory wells, at water depths ranging from between 252 and $419 \mathrm{~m}$. At the time, oil and gas production reached 33,000 bopd and $430 \mathrm{~m}^{3} / \mathrm{d}$, respectively. Phase II would add 95 wells, completed in Namorado, Eocene and Oligocene 1, 2, and 3 reservoirs, and a few in Miocene and Oligo-Miocene units, to gather information. 39 injectors will be activated. This phase was divided in 2 steps. First, all possible alternatives and economical screening was used. The remaining cases were then optimized.

The challenge for developing offshore deep water oil fields led to a paradigm that differs from the 70's and 80's view, when closely-spaced vertical wells was the way-to-go. This is something that characterizes most of the onshore developments and early cases in the offshore, such as Namorado Field, in relatively shallow waters. In the new scenario, with a need to reduce the number of wells, largely spaced or multilateral wells are required. Another important challenge was to describe some the internal heterogeneities of turbiditic reservoirs. Although facies can be described from cores, scare information is available for interwell areas. One feature of Campos basin turbidites is the lack of outcrops that would facilitate the finding of analogues.

To illustrate the internal complexity of some offshore reservoirs that may have an impact on IOR activities, let us briefly review a paper by Barroso et al. [251]. These authors refer to the turbiditic reservoir Albacora, identified with the Namorado sandstone, a Cretaceous in age sediment. A relatively detailed stratigraphic description of Namorado sequences is reported. From the point of view of dynamics, calcite cementation (1-53 vol\%) is the most important porosity and permeability control of the Namorado sandstone, which range $1.8 \%<\phi<32 \%$ and $0.1 \mathrm{mD}<\mathrm{K}<1,624 \mathrm{mD}$.

Marlim Complex. De Macedo and Asrilhant [254] describe drainage grid alternatives, production philosophy, subsea arrangements, and oil and gas exporting shorewards for the Marlim Field development plan. They went into demonstrating the profitability of the Phase I project. The Marlim complex is a system of oil accumulations located nearly $100 \mathrm{~km}$ from the coast, in the Campos basin and extends an area over $381 \mathrm{Km}^{2}$ (94,100 acres), at water depths ranging from $400 \mathrm{~m}$ to $1,800 \mathrm{~m}$ $(1,312$ to $5,906 \mathrm{ft})$. The estimated STOOIP at the time was $2.2 \times 10^{9} \mathrm{~m}^{3}\left(14 \times 10^{9} \mathrm{bbl}\right)$, representing $32 \%$ of the total Brazilian STOOIP.

The Marlim Field was discovered in February 1985 at $837 \mathrm{~m}$ of water depth. The estimated STOOIP was $1.3 \times 10^{9} \mathrm{~m}^{3}\left(8.2 \times 10^{9} \mathrm{bbl}\right)$ and $108 \mathrm{~m}^{3}\left(3.5 \times 10^{9} \mathrm{ft}^{3}\right)$ of gas in place, at water depths between 660 and 1,000 m. The proposed development plans was to be developed in three stages, Pilot Production System, Phase I and Phase II. Water injection initiated in the oil leg with Phase I, some 15 months after the pilot (there was no apparent aquifer). Well spacing considered was $1,1.4$ and $2 \mathrm{Km}$, being the shortest spacing the most profitable. Oil density averages between 10 to $20^{\circ} \mathrm{API}$ gravity. Because of the great depth and shallowness of the reservoir, highly inclined wells were necessary (most of them were seabed completed).

Later, Capeleiro [255] presented some aspects of the Reservoir Engineering and development plan of the Marlim Field and how the experience was used for the neighbor fields, Marlim Sul and Marlim 
Leste. At this time, more than $50 \%$ of the Brazilian oil production came from the offshore fields at water depths over 1,000 m. By 2001, Marlim Field was producing 85,000 m³ $/ \mathrm{d}$ (535,000 bopd), from 60 producers and 32 water injectors. This medium oil field presents excellent petrophysical properties and good vertical communication. The oil is sub-saturated, with viscosity values between 4 and $8 \mathrm{cp}$. This combination of properties makes water pressure maintenance an efficient process. However, paraffin deposition in flowlines represents a problem for Marlim Field. To sustain the roughly 540,000 bopd, 640,000 bwpd were being injected. The recovery factor by 2001 reached 7.2\%.

Pressure maintenance is carried out by injecting seawater in an alternate line drive pattern in the oil leg. Good reservoir properties and high vertical permeability, water injection tends to be stable, and hence efficient in the Marlim Complex. Although water injection is the only IOR process used in the Marlim Complex, polymer injection and WAG have been studied alternatives, but not implemented.

\subsubsection{California Onshore}

An emblematic onshore reservoir containing important turbiditic deposits is the Elk Hills Field [256]. This field has been discussed previously in this article, but it is worth mentioning, because it reflects that EOR is mostly constrained in this environments by operational conditions, such as those found in the offshore. This field has been extensively subject to thermal methods, which are unlikely to work in the offshore. However, $\mathrm{CO}_{2}$ flooding, alkaline, enriched gas injection and other methods have been considered viable in this field [257].

The Midway Sunset Field [258] represents another example of an onshore turbiditic deposit in California (Bakersfield area). The traditional scheme again is a form of steamflooding (or stimulation).

\subsubsection{North Sea Offshore}

Although a more detailed discussion on offshore is provided in the next section, it is interesting to advance the idea that $\mathrm{CO}_{2}$ flooding has been given serious consideration in offshore environments. An example of a detailed study is associated with the Forties Field [259]. The field is located $170 \mathrm{~km} \mathrm{NE}$ of Aberdeen. Significant incremental could, in principle, be obtained in a process like this. Internal complexities of turbiditic reservoirs must be resolved in order to mitigate uncertainties in this depositional environments.

\section{EOR Offshore}

EOR in offshore fields is not only constrained by reservoir lithology, as was described in earlier section of this article, but also by surface facilities and environmental regulations, among other factors [165,260,261]. Therefore, availability of EOR options in offshore fields is more limited than the onshore counterparts. The main drainage strategy in offshore fields has been pressure maintenance by gas and water injection. Figure 7 shows the statistics of oil recovery projects in the North Sea [262-265] as well as EOR opportunities in offshore Malaysia [266-270]. 
Figure 7. Examples of EOR in offshore fields: (a) North Sea EOR Projects (From Awan et al., [262]) and, (b) EOR Opportunities Offshore Malaysia (From Samsudin et al., [268]).

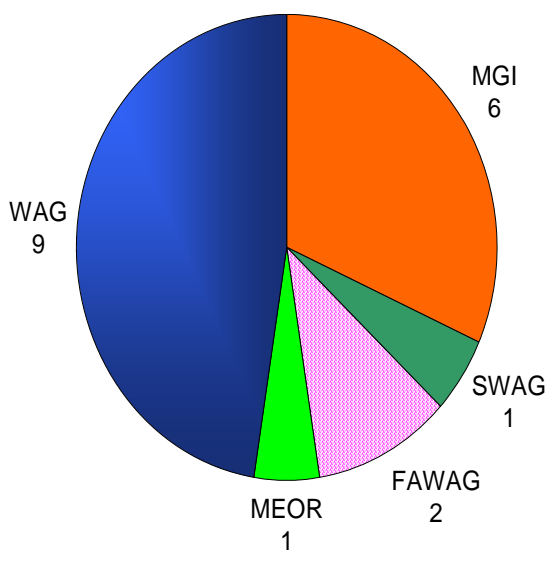

(a)

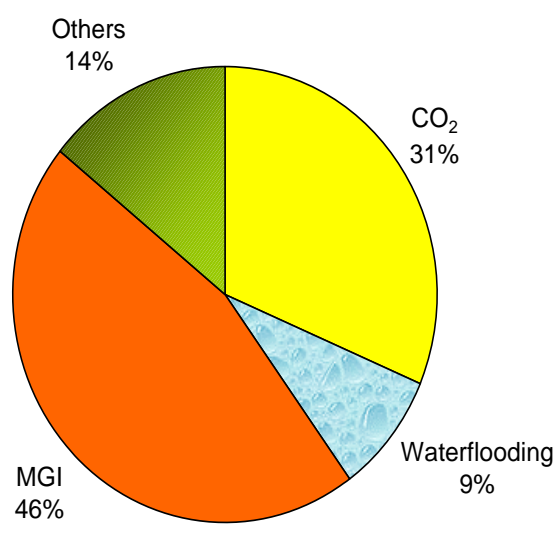

(b)

On the other hand, Figure 8 shows oil production in the U.S. Gulf of Mexico (GOM) in shallow and deep waters since 1990 and the forecast until the year 2013. GOM oil production is mainly supported by water and/or gas injection [271-273]. Despite environmental conditions in the area (e.g., hurricane seasons), oil production from deep waters in GOM is expected to continue to increase in the future mostly based on conventional recovery methods rather than EOR projects [274-277]. Mexico is another example of offshore reservoir production supported by gas injection, bottom water drive, and/or water injection. Regarding gas injection, it is important to note that Cantarell/Akal represents the largest $\mathrm{N}_{2}$ injection project in the world [214,278,279].

Figure 8. Historic and forecast oil production rates of U.S. GOM shallow and deep water projects (E = Estimated) (From MMS, 2005 [273]).

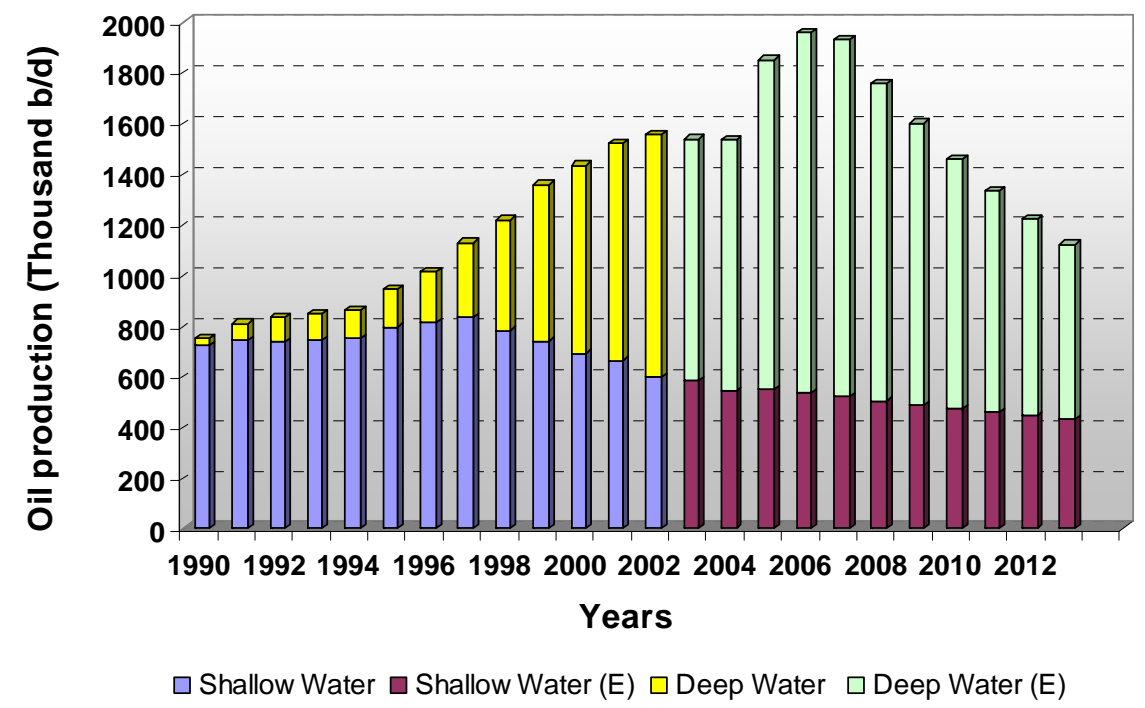

Similar to previous examples, most offshore environments are under continuous optimization strategies of gas and waterflooding to extend field production life and maximize oil recovery [261,279-284]. Several 
EOR methods have been tested or have been proposed for offshore fields; however, only a few cases are listed in this review:

- $\mathrm{CO}_{2}$ EOR/Sequestration has been proposed during the last decade [21,239,261,285,286]. $\mathrm{CO}_{2}$-EOR, from produced gas, has been tested in Dulang Field, Malaysia [268]). Most recently Liner [287] suggests that $\mathrm{CO}_{2}$ storage in offshore fields will be a preferred option compared to onshore fields. Although this study does not address EOR potential of $\mathrm{CO}_{2}$, main reasons to suggest that $\mathrm{CO}_{2}$ storage in offshore fields represents the most reasonable strategy is based on safety (e.g., risk associated to $\mathrm{CO}_{2}$ leakage) and good quality seismic data commonly available in offshore environments and required for reservoir description and $\mathrm{CO}_{2}$ monitoring. $\mathrm{CO}_{2}$-EOR and storage in offshore fields can be based on anthropogenic sources of captured produced gases in offshore fields or from $\mathrm{CO}_{2}$ piped from onshore facilities.

- High-pressure air injection (HPAI) has been proposed (e.g., Ekofisk, North Sea), but has not yet been tested for technical and economical reasons [288,289]. Mexico has also considered the potential of air injection in offshore fields [194]. However, we do not foresee offshore implementation of HPAI in the near term.

- Although field applications of chemical EOR methods in offshore fields have not been widely documented in the literature, a few examples can be provided:

o FAWAG (Foam Assisted WAG) to improve gas mobility control based on a chemical method was successfully tested in Snorre Field, Norwegian North Sea [261-290].

o Single-well Alkali-Surfactant-Polymer (ASP) combined with single-well partitioning tracers before and after the ASP injection was successfully evaluated in Lagomar Field, Maracaibo Lake, Venezuela (Hernández et al., [291], Manrique et al., [292]).

o Single-well Alkali-Surfactant (AS) combined with single-well partitioning tracers before and after the AS injection was successfully evaluated in Angsi Field, offshore Terengganu, Malaysia [293].

- Polymer flooding has gained recent interest for offshore EOR applications including the injection of Colloidal Dispersion Gels or CDG [18,27,114]. Some examples of proposed or field polymer flood test include:

o Dos Cuadras Field, offshore California [294].

o Dalia single well pilot in Camelia reservoir, offshore Angola (Morel et al., [295]).

o Pilot test of polymer flooding (hydrophobically associating water-soluble polymer or HAWP) conducted in SZ36-1 heavy oil field of Bohai Bay, offshore China [296,297].

Although there are several initiatives to evaluate EOR potential in offshore fields, most of them are at early stages or might not be economically attractive with the current technology. Therefore, it is expected that commercial applications of EOR methods would not likely take place for at least a decade or two. Surface facility constraints and environmental regulations (e.g., chemical additives for EOR) also represent major hurdles for large EOR applications in offshore fields. Offshore EOR projects are capital-intensive. If we add the volatility of energy markets, the risk associated with this type of projects is high, reducing the probability of implementation. Therefore, waterflooding and gas injection and their combined injection schemes (e.g., WAG) in conjunction with injection profile 
modification and/or gas or water shut-off (i.e., foams, gels, and in-depth gel treatments such as BrightWater $\left.{ }^{\circledR}\right)$ strategies will continue to support offshore production in the near term.

\section{Conclusions}

Thermal methods, specifically steam injection, still dominate as the preferred EOR method for heavy oil reservoirs. As of today, SAGD seems to be a technology only applicable to Canadian Oil Sands and more specifically in the McMurray formation. High-pressure air injection (HPAI) represents one of the thermal recovery processes showing an increased interest in recent years in both carbonate and sandstone formations. However, HPAI field projects are still concentrated in the low permeable dolomitic Red River formation of Montana and North and South Dakota. Lack of understanding and dissemination of information regarding HPAI designs and risk mitigation have been probably responsible for the limited number of cases deployed as full-field projects, despite significant success in ongoing projects.

Hydrocarbon gas injection (continuous or in a WAG mode) continues to be the preferred recovery process in offshore fields, gas condensate reservoirs, or fields in remote locations without access to gas markets. $\mathrm{N}_{2}$ EOR projects seem to be in decline except in the Campeche Bay Area in Mexico because of the availability of vast installed $\mathrm{N}_{2}$ generation capacity. $\mathrm{CO}_{2}$ injection is getting most of the attraction as an EOR method and potentially as a sequestration strategy in recent years. However, $\mathrm{CO}_{2}$-EOR projects in operation are mostly concentrated in the U.S. (especially in the Permian Basin) and associated to natural sources of $\mathrm{CO}_{2} \cdot \mathrm{CO}_{2}$-EOR/sequestration projects are not expected to grow in the near future until industrial sources of $\mathrm{CO}_{2}$ are produced at much lower costs and the proper regulatory framework is in place.

Chemical EOR methods have made a relatively small contribution to the world's oil production during the last decades. China is the country with the largest oil production coming from Chemical EOR projects. However, there are an increasing number of ongoing and planned SP and ASP evaluations at pilot scale, especially in Canada and the U.S. Polymer flooding is gaining interest for heavy crude oil reservoirs (i.e., Canada) and offshore fields. However, chemical EOR is not expected to impact world's oil production for at least two decades, if it is ever implemented at commercial scales.

The combination of conformance technologies (gel treatments) to improve injection profile and sweep efficiency with chemical EOR flooding such as CDG, SP, or ASP is starting to gain more interest from operators in South America and the U.S. based on El Tordillo Field successful experience in Argentina.

Despite the growing research interest on chemically assisted methods (e.g., spontaneous imbibition, wettability modifiers and ITF reductions) and surfactant-polymer (SP) flooding to improve oil recoveries in carbonate formations, these projects are not expected to impact global oil production in the near future.

\section{Acknowledgements}

The Authors would like to thank TIORCO, NALCO and STEPAN for permission to publish this paper. 


\section{References}

1. Bleakley, W.B. Production Report: Journal Survey Shows Recovery Projects Up. Oil Gas J. 1974, 72, 69-76, 78.

2. Noran, D. Enhanced Recovery Action is Worldwide. Oil Gas J. 1976, 74, 107-108, 110-114, 119-122, 124-131.

3. Noran, D. Production Report: Growth Marks Enhanced Oil Recovery. Oil Gas J. 1978, 76, 113-140.

4. Matheny, S.L. Production Report: EOR methods help ultimate recovery. Oil Gas J. 1980, 78, 79-124.

5. Leonard, J. Annual Production Report: Steam dominates enhanced oil recovery. Oil Gas J. 1982, 80, 139-146, 152-159.

6. Leonard, J. Annual Production Report: EOR set to make significant contribution. Oil Gas J. 1984, 82, 83-90, 92-95, 98-105.

7. Leonard, J. Production/Enhanced Oil Recovery Report: Increased rate of EOR brightens outlook. Oil Gas J. 1986, 84, 71-89.

8. Aalund, L.R. Annual Production Report: EOR projects decline but $\mathrm{CO}_{2}$ pushes up production. Oil Gas J. 1988, 86, 33-74.

9. Moritis, G. $\mathrm{CO}_{2}$ and HC Injection Lead EOR Production Increase. Oil Gas J. 1990, 88, 49-82.

10. Moritis, G. EOR Production Report. Oil Gas J. 1992, 90, 60-65, 68-73, 76-78.

11. Moritis, G. EOR Production Report. Oil Gas J. 1994, 92, 60-69, 72-78.

12. Moritis, G. 1996 EOR Worldwide Survey. Oil Gas J. 1996, 94, 45-61.

13. Moritis, G. 1998 EOR Worldwide Survey. Oil Gas J. 1998, 96, 60-65, 68-71, 74-77.

14. Moritis, G. EOR weathers low oil prices. Oil Gas J. 2000, 98, 39-42, 44-53, 56-61.

15. Moritis, G. Special Report: Enhanced Oil Recovery. Oil Gas J. 2002, 100, 72-83.

16. Moritis, G. EOR continues to unlock oil resources. Oil Gas J. 2004, 102, 45, 48-50, 52-65.

17. Moritis, G. 2006 Worldwide EOR Survey. Oil Gas J. 2006, 104, 46-57.

18 Moritis, G. 2008 Worldwide EOR Survey. Oil Gas J. 2008, 106, 41-42, 44-59.

19. Manrique, E.J.; Muci, V.E.; Gurfinkel, M.E. EOR Field Experiences in Carbonate Reservoirs in the United States. SPE Reserv. Eval. Eng. 2007, 10, 667-686.

20. Moritis, G. Future of EOR \& IOR: New companies, infrastructure, projects reshape landscape for $\mathrm{CO}_{2}$ EOR in the US. Oil Gas J. 2001, 99, 68-69, 72-73.

21. Hustad, C.W. Capturing, Managing and Gathering $\mathrm{CO}_{2}$ for EOR Onshore and Offshore: Challenges and Opportunities. Presented at the ACI Optimising EOR Strategy, London, UK, 11-12 March 2009.

22. Crude oil price: Refiner average domestic crude oil acquisition cost (April 2009). Available online: http://tonto.eia.doe.gov/dnav/pet/hist_xls/R1200 3m.xls. (accessed on 11 August 2010).

23. Taber, J.J.; Martin, F.D.; Seright, R.S. EOR Screening Criteria Revisited-Part I: Introduction to Screening Criteria and Enhanced Oil Recovery Projects. SPE Reserv. Eng. 1997, 12, 189-198.

24. Taber, J.J.; Martin, F.D.; Seright, R.S. EOR Screening Criteria Revisited—Part II: Applications and Impact of Oil Price. SPE Reserv. Eng. 1997, 12, 199-205. 
25. Amato, F.L. Petroleum Developments in South America, Central America, Mexico, and Caribbean Area in 1978. AAPG Bull. 1979, 63, 1745-1803.

26. Shecaira, F.S.; Branco, C.C.M.; de Souza, A.L.S.; Pinto, A.C.C.; de Holleben, C.R.C.; Johann, P.R.S. IOR: The Brazilian Perspective (SPE-75170). In Proceedings of SPE/DOE Improved Oil Recovery Symposium, Tulsa, OK, USA, 13-17 April 2002.

27. de Melo, M.A.; de Holleben, C.R.C.; da Silva, I.P.G.; de Barros, C.; da Silva, G.A.; Rosa, A.J.; Lins A.G.; de Lima J.C. Evaluation of Polymer Injection Projects in Brazil (SPE-94898). In Proceedings of SPE Latin American and Caribbean Petroleum Engineering Conference, Rio de Janeiro, Brazil, 20-23 June 2005.

28. Lino, U.R.A. Case History of Breaking a Paradigm: Improvement of an Immiscible GasInjection Project in Buracica Field by Water Injection at the Gas/Oil Contact (SPE-94978). In Proceedings of SPE Latin American and Caribbean Petroleum Engineering Conference, Rio de Janeiro, Brazil, 20-23 June 2005.

29. Rocha, P.S.; Dino, R.; Sanches, C.; Le Thiez, P. Assessing the $\mathrm{CO}_{2}$ Storage as a By-Product of EOR Activities in the Buracica Oil Field-Recôncavo Basin, NE Brazil. In Proceedings of 6th Annual Conference on Carbon Capture \& Sequestration, Pittsburgh, PA, USA, 7-10 May 2007.

30. Le Thiez, P.A. Quick Overview of (some) CCS Projects Around the World. In Proceedings of Carbon Sequestration Leadership Forum: Capacity Building Workshop, Salvador, Brazil, 8-9 September 2008.

31. da Silva, I.P.G.; de Melo, M.A.; Luvizotto, J.M.; Lucas, E.F. Polymer Flooding: A Sustainable Enhanced Oil Recovery in the Current Scenario (SPE-107727). In Proceedings of Latin American \& Caribbean Petroleum Engineering Conference, Buenos Aires, Argentina, 15-18 April 2007.

32. de Souza, J.C.; da S. Cursino, D.F.; de O. Pádua, K.G. Twenty Years of Steam Injection in Heavy-Oil Fields (SPE-94808). In Proceedings of SPE Latin American and Caribbean Petroleum Engineering Conference, Rio de Janeiro, Brazil, 20-23 June 2005.

33. Mezzomo, R.F.; Luvizotto, J.M.; Palagi, C.L. Improved Oil Recovery in Carmópolis Field: R\&D and Field Implementations. SPE Reserv. Eval. Eng. 2001, 4, 4-10.

34. Pinto, da C.P.H.L.; Silva Jr., M.F.; Izetti, R.G.; Guimarães, G.B. Integrated Multizone Low-Cost Intelligent Completion for Mature Fields (SPE-99948). In Proceedings of Intelligent Energy Conference and Exhibition, Amsterdam, The Netherlands, 11-13 April 2006.

35. Chakabaev, S.E.; Ivanov, V.A.; Shakhovoi, A.I.; Tokarev, V.P. 1978. Injection of Water Thickened by Polyacrylamide-Industrial Experiment in the Karazhanbas Field, (in Russian). Geol. Nefti Gaza 1978, 1, 7-12.

36. Mamedov, Y.G.; Bokserman, A.A. Application of Improved Oil Recovery in the Soviet Union (SPE 24162). In Proceedings of 8th SPE/DOE Enhanced Oil Recovery Symposium, Tulsa, OK, USA, 22-24 April 1992.

37. Antoniadi, D.G.; Arzhanov, F.G.; Garushev, A.R.; Ishkhanov, V.G. Thermal Recovery Methods at the Former SU Oil Fields, (in Russian). Neft. Khoz. 1993, 10, 24-25, 28-29.

38. Zhdanov, S.A.; Amiyan, A.V.; Surguchev, L.M.; Castanier, L.M.; Hanssen, J.E. Application of Foam for Gas and Water Shut-Off: Review of Field Experience (SPE 36914). In Proceedings of SPE European Petroleum Conference, Milan, Italy, 22-24 October 1996. 
39. Collins, P.M.; Dusseault, M.B.; Dorscher, D.; Kueber, E. Implementing CHOPS in the Karazhanbas Heavy Oil Field, Kazakhstan (Paper 2008-500). In proceedings of World Heavy Oil Congress, Edmonton, Canada, 10-12 March, 2008.

40. De Haan, H.J.; Van Lookeren, J. Early Results of the First Large-Scale Steam Soak Project in the Tia Juana Field, Western Venezuela. J. Pet. Technol. 1969, 21, 101-110.

41. Ernandez J. EOR Projects in Venezuela: Past and Future. Presented at the ACI Optimising EOR Strategy 2009, London, UK, 11-12 March 2009.

42. Hanzlik, E.J. Forty Years of Steam Injection in California-The Evolution of Heat Management (SPE-84848). In Proceedings of SPE International Improved Oil Recovery Conference in Asia Pacific, Kuala Lumpur, Malaysia, 20-21 October 2003.

43. Ramlal, V. Enhanced oil recovery by steamflooding in a recent steamflood project, Cruse "E" Field, Trinidad (SPE-89411). In Proceedings of 14th SPE/DOE IOR Symposium, Tulsa, OK, USA, 17-21 April 2004.

44. Jelgersma, F. Redevelopment of the Abandoned Dutch Onshore Schoonebeek Oilfield With Gravity Assisted Steam Flooding (IPTC-11700). In Proceedings of International Petroleum Technology Conference, Dubai, 4-6 December 2007.

45. Lacerda, G.M.; Patriota, J.H.; Pereira, J.I.; Torres J.S.; De Lima, L.A. Alto do Rodrigues GeDIg Pilot-Case Study for Continuous Steam Injection Recovery Combined with Real-Time Operation (SPE-112242). In Proceedings of Intelligent Energy Conference and Exhibition, Amsterdam, The Netherlands, 25-27 February 2008.

46. Rivero, J.A.; Mamora, D.D. Oil Production Gains for Mature Steamflooded Oil Fields Using Propane as a Steam Additive and a Novel Smart Horizontal Producer (SPE-110538). In Proceedings of SPE Annual Technical Conference and Exhibition, Anaheim, CA, USA, 11-14 November 2007.

47. Bagci, A.S.; Gumrah, F. Effects of $\mathrm{CO} 2$ and $\mathrm{CH} 4$ Addition to Steam on Recovery of West Kozluca Heavy Oil (SPE-86953). In Proceedings of SPE International Thermal Operations and Heavy Oil Symposium and Western Regional Meeting, Bakersfield, CA, USA, 16-18 March 2004.

48. Ovalles, C.; Vallejos, C.; Vasquez, T.; Martinis, J.; Perez-Perez, A.; Cotte, E.; Castellanos, L.; Rodriguez, H. Extra-Heavy Crude Oil Downhole Upgrading Process using Hydrogen Donors under Steam Injection Conditions (SPE-69692). In Proceedings of SPE International Thermal Operations and Heavy Oil Symposium, Porlamar, Venezuela, 12-14 March 2001.

49. Mendez, Z.; Alvarez, J.M.; Escobar, E.; Colonomos, P., Campos, E. Cyclic Steam Injection With Additives: Laboratory and Field Test Results of Steam/Foam and Steam/Solvent Processes (SPE-24632). In Proceedings of SPE Annual Technical Conference and Exhibition, Washington, DC, 4-7 October 1992.

50. Mbaba, P.E.; Caballero, E.P. Field Application of an Additive Containing Sodium Metasilicate During Steam Stimulation (SPE-12058). In Proceedings of SPE Annual Technical Conference and Exhibition, San Francisco, CA, USA, 5-8 October 1983.

51. Leaute, R.P. Liquid Addition to Steam for Enhancing Recovery (LASER) of Bitumen with CSS: Evolution of Technology from Research Concept to a Field Pilot at Cold Lake (SPE-79011). In 
Proceedings of SPE International Thermal Operations and Heavy Oil Symposium and International Horizontal Well Technology Conference, Calgary, AB, Canada, 4-7 November 2002.

52. Perez-Perez, A.; Gamboa, M.; Ovalles, C.; Manrique, E. Benchmarking of Steamflood Field Projects in Light/Medium Crude Oils (SPE-72137). In Proceedings of SPE Asia Pacific Improved Oil Recovery Conference, Kuala Lumpur, Malaysia, 6-9 October 2001.

53. Manrique, E.; Pereira, C. Identifying Viable EOR Thermal Processes in Canadian Tar Sands (Paper CIPC 2007-176). In Proceedings of 8th Canadian International Petroleum Conference (58th Annual Technical Meeting), Calgary, AB, Canada, 12-14 June 2007.

54. Li-qiang, Y.; Da-sheng, Z.; Yu-huan, S. SAGD as Follow-Up to Cyclic Steam Stimulation in a Medium Deep and Extra Heavy-Oil Reservoir (SPE-104406). In Proceedings of International Oil \& Gas Conference and Exhibition, Beijing, China, 5-7 December 2006.

55. Grills, T.L.; Vandal, B.; Hallum, F.; Trost, P. Case History: Horizontal Well SAGD Technology is Successfully Applied to Produce Oil at LAK Ranch in Newcastle Wyoming (SPE-78964). In Proceedings of SPE International Thermal Operations and Heavy Oil Symposium and International Horizontal Well Technology Conference, Calgary, AB, Canada, 4-7 November 2002.

56. Mendoza, H.A.; Finol, J.J.; Butler, R.M. SAGD, Pilot Test in Venezuela (SPE-53687). In Proceedings of Latin American and Caribbean Petroleum Engineering Conference, Caracas, Venezuela, 21-23 April 1999.

57. Scott, G.R. Comparison of CSS and SAGD Performance in the Clearwater Formation at Cold Lake (SPE/CIM/CHOA-79020). SPE/PS-CIM/CHOA Int. In Proceedings of Thermal Operations and Heavy Oil Symposium and Int. Horizontal Well Technology Conference, Calgary, AB, Canada, 4-7 November 2002.

58. Rottenfusser, B.; Ranger, M.A. Geological Comparison of Six Projects in the Athabasca Oil Sands. In Proceedings of CSPG-Canadian Heavy Oil Association-CWLS Joint Conf. (ICE2004), Calgary, AB, Canada, 31 May-4 June 2004.

59. Putnam, P.E.; Christensen, S.L. McMurray Formation SAGD (Steam-Assisted Gravity Drainage) Reservoirs in Northeastern Alberta: Comparative Architecture and Performance. In Proceedings of CSPG-Canadian Heavy Oil Assoc.-CWLS Joint Conf. (ICE2004), Calgary, AB, Canada, 31May-4 June 2004.

60. Jimenez, J. The Field Performance of SAGD Projects in Canada (IPTC-12860). In Proceedings of International Petroleum Technology Conference, Kuala Lumpur, Malaysia, 3-5 December 2008.

61. Stalder, J.L. Thermal Efficiency and Acceleration Benefits of Cross SAGD (XSAGD)-(SPE117244). In Proceedings of International Thermal Operations and Heavy Oil Symposium, Calgary, AB, Canada, 20-23 October 2008.

62. Shin, H.; Polikar, M. Fast- SAGD Application in the Alberta Oil Sands Areas (Paper 2005-173). In Proceedings of Petroleum Society's 6th Canadian International Petroleum Conference-56th Annual Technical Meeting), Calgary, AB, Canada, 7-9 June 2005.

63. Elliot, K.T.; Kovscek, A.R. A Numerical Analysis of the Single-Well Steam Assisted Gravity Drainage (SW-SAGD) Process; SUPRI TR-124; Technical Report for U.S. Department of Energy: Tulsa, OK, USA, 2001. 
64. Govind, P.A.; Das, S.; Srinivasan, S.; Wheeler, T.J. Expanding Solvent SAGD in Heavy Oil Reservoirs (SPE-117571). In Proceedings of International Thermal Operations and Heavy Oil Symposium, Calgary, AB, Canada, 20-23 October 2008.

65. Machedon, V.; Popescu, T.; Paduraru, R. Romania-30 Years of Experience in In situ Combustion. In Proceedings of U.S. DOE Field Application of In situ Combustion-Past Performance/Future Applications Symposium, Tulsa, OK, USA, 21-22 April 1994; pp. 83-96.

66. Panait-Paticaf, A.; Åžerban, D.; Ilie, N. Suplacu de Barcau Field-A Case History of a Successfull In-situ Combustion Exploitation (SPE-100346). SPE Europec/EAGE Annual Conference and Exhibition, Vienna, Austria, 12-15 June 2006.

67. Sharma, S.K.; Kak, H.L.; Meena, H.L.; Pratap, V. EOR Process In Balol-Santhal Fields, India's Honeymoon With In-situ Combustion: An Overview. In Proceedings of 5th Indian Oil Corp. Ltd. International Petroleum Conference, New Delhi, India, 9-12 January 2003.

68. Roychaudhury, S.; Rao, N.S.; Sinha, S.K.; Sur, S.; Gupta, K.K.; Sapkal, A.V., Jain, A.K.; Saluja, J.S. Extension of In-situ Combustion Process from Pilot to Semi-Commercial Stage in Heavy Oil Field of Balol (SPE-37547). In Proceedings of International Thermal Operations and Heavy Oil Symposium, Bakersfield, CA, USA, 10-12 February 1997.

69. Chattopadhyay, S.K.; Ram, B.; Bhattacharya, R.N.; Das, T.K. Enhanced Oil Recovery by In-situ Combustion Process in Santhal Field of Cambay Basin, Mehsana, Gujarat, India-A Case Study (SPE-89451). In Proceedings of SPE/DOE Symposium on Improved Oil Recovery, Tulsa, OK, USA, 17-21 April 2004.

70. Doraiah, A.; Ray, S.; Gupta, P. In-situ Combustion Technique to Enhance Heavy-Oil Recovery at Mehsana, ONGC - A Success Story (SPE-105248). In Proceedings of SPE Middle East Oil and Gas Show and Conference, Bahrain, 11-14 March 2007.

71. Long, R.E.; Nuar, M.F. A Study of Getty Oil Co.'s Successful In-situ Combustion Project in the Bellevue Field (SPE-10708). In Proceedings of SPE Enhanced Oil Recovery Symposium, Tulsa, OK, USA, 4-7 April 1982.

72. Gillham, T.H.; Cerveny, B.W.; Turek, E.A.; Yannimaras, D.V. Keys to Increasing Production Via Air Injection in Gulf Coast Light Oil Reservoirs (SPE-38848). In Proceedings of SPE Annual Technical Conference and Exhibition, San Antonio, TX, USA, 5-8 October 1997.

73. Gillham, T.H.; Cerveny, B.W.; Fornea, M.A.; Bassiouni, D.Z. Low Cost IOR: An Update on the W. Hackberry Air Injection Project (SPE-39642). In Proceedings of SPE/DOE Improved Oil Recovery Symposium, Tulsa, OK, USA, 19-22 April 1998.

74. Duiveman, M.W.; Herwin, H.; Grivot, P. Integrated Management of Water, Lean Gas and Air Injection: The Successful Ingredients to IOR Projects on the Mature Handil Field (SPE-93858). In Proceedings of SPE Asia Pacific Oil and Gas Conference and Exhibition, Jakarta, Indonesia, 5-7 April 2005.

75. Hongmin, Y.; Baoquan, Y.; Guorui, X.; Jiexiang, W.; Shao, R.R.; .Weimin, L.; Liang, X.; Haitao, G. Air Foam Injection for IOR: From Laboratory to Field Implementation in ZhongYuan Oilfield China (SPE-113913). In Proceedings of SPE/DOE Symposium on Improved Oil Recovery, Tulsa, OK, USA, 20-23 April 2008. 
76. Hughes, B.L.; Sarma, H.K. Burning Reserves For Greater Recovery? Air Injection Potential In Australian Light Oil Reservoirs (SPE-101099). In Proceedings of SPE Asia Pacific Oil \& Gas Conference and Exhibition, Adelaide, Australia, 11-13 September 2006.

77. Sarma H.; Das, S. Air Injection Potential in Kenmore Oilfield in Eromanga Basin, Australia: A Screening Study Through Thermogravimetric and Calorimetric Analyses (SPE-120595). In Proceedings of SPE Middle East Oil and Gas Show and Conference, Bahrain, The Kingdom of Bahrain, 15-18 March 2009.

78. Teramoto, T.; Takabayashi, K.; Onishi, T.; Okatsu, K. Air Injection EOR in highly water saturated oil reservoir. In Proceedings of IEA Collaborative Project on Enhanced Oil Recovery 25th Annual Workshop and Symposium, Stavanger, Norway, 5-8 September 2005.

79. Onishi, T.; Katoh, K.; Takabayashi, K.; Uematsu, H.; Okatsu, K.; Wada, Y.; Ogata, Y. High Pressure Air Injection into Light Oil Reservoirs: Experimental Study on Artificial Ignition. In Proceedings of IEA Collaborative Project on Enhanced Oil Recovery 28th Annual Workshop and Symposium, Vedbæk, Denmark, 4-7 September 2007.

80. Xia, T.X.; Greaves, M.; Turta, A.T. Injection Well—Producer Well Combinations in THAI 'Toeto-Heel Air Injection (SPE-75137). In Proceedings of SPE/DOE Improved Oil Recovery Symposium, Tulsa, OK, USA, 13-17 April 2002.

81. Greaves, M.; Xia, T.X.; Ayasse, C. Underground Upgrading of Heavy Oil Using THAI- "Toe-toHeel Air Injection" (SPE-97728). In Proceedings of SPE/PS-CIM/CHOA International Thermal Operations and Heavy Oil Symposium, Calgary, AB, Canada, 1-3 November 2005.

82. Xia, T.X.; Greaves, M.; Werfilli, W.S., Rathbone, R.R. Downhole Conversion of Lloydminster Heavy Oil Using THAI-CAPRI Process (SPE-78998). In Proceedings of SPE International Thermal Operations and Heavy Oil Symposium and International Horizontal Well Technology Conference, Calgary, AB, Canada, 4-7 November 2002.

83. WHITESANDS Project-Petrobank Energy and Resources Ltd. Available online: http://www.petrobank.com/hea-whitesandsproject.html (accessed on 23 October 2010).

84. Eson, R.L. Downhole Steam Generator-Field Tests (SPE-10745). In Proceedings of SPE California Regional Meeting, San Francisco, CA, USA, 24-26 March 1982.

85. Donaldson, A.B. Reflections on a Downhole Steam Generator Program (SPE-38276). In Proceedings of SPE Western Regional Meeting, Long Beach, CA, USA, 25-27 June 1997.

86. Sierra, R.; Tripathy, B.; Bridges, J.E.; Farouq Ali, S.M. Promising Progress in Field Application of Reservoir Electrical Heating Methods (SPE-69709). In Proceedings of SPE International Thermal Operations and Heavy Oil Symposium, Margarita Island, Venezuela, 12-14 March 2001.

87. Hascakir, B.; Babadagli, T.; Akin, S. Experimental and Numerical Modeling of Heavy-Oil Recovery by Electrical Heating (SPE-117669). In Proceedings of International Thermal Operations and Heavy Oil Symposium, Calgary, AB, Canada, 20-23 October 2008.

88. Rodríguez, R.; Bashbush, J.L.; Rincón, A. Feasibility of using Electrical Downhole Heaters in Faja Heavy Oil Reservoirs (SPE-117682). In Proceedings of International Thermal Operations and Heavy Oil Symposium, Calgary, AB, Canada, 20-23 October 2008.

89. Islam, M.R.; Wadadar, S.S.; Bansal, A. Enhanced Oil Recovery of Ugnu Tar Sands of Alaska Using Electromagnetic Heating With Horizontal Wells (SPE-22177). In Proceedings of International Arctic Technology Conference, Anchorage, AK, USA, 29-31 May 1991. 
90. Das, S. Electro-Magnetic Heating in Viscous Oil Reservoir (SPE-117693). In Proceedings of International Thermal Operations and Heavy Oil Symposium, Calgary, AB, Canada, 20-23 October 2008.

91. Hascakir, B.; Acar, C.; Demiral, B.; Akin, S. Microwave Assisted Gravity Drainage of Heavy Oils (IPTC-12536). In Proceedings of International Petroleum Technology Conference, Kuala Lumpur, Malaysia, 3-5 December 2008.

92. Needham, R.B.; Doe, P.H. Polymer Flooding Review. J. Pet. Technol. 1987, 39, 1503-1507.

93. Han, D.K.; Yang, C.Z.; Zhang, Z.Q.; Lou, Z.H.; Chang, Y.I. Recent development of enhanced oil recovery in China. J. Pet. Sci. Eng. 1999, 22, 181-188.

94. Delamaide, E.; Corlay, P.; Wang, D. Daqing Oil Field: The Success of Two Pilots Initiates First Extension of Polymer Injection in a Giant Oil Field (SPE-27819). In Proceedings of SPE/DOE Improved Oil Recovery Symposium, Tulsa, OK, USA, 17-20 April 1994.

95. Wang, D.; Cheng, J.; Wu, J.; Wang, G. Experiences Learned after Production of more than 300 million Barrels of Oil by Polymer Flooding in Daqing Oil Field (SPE-77693). In Proceedings of SPE Annual Technical Conference and Exhibition, San Antonio, TX, USA, 29 September2 October 2002.

96. Chang, H.L.; Zhang, Z.Q.; Wang, Q.M.; Xu, Z.S.; Guo, Z.D.; Sun H.Q.; Cao, X.L.; Qiao, Q. Advances in Polymer Flooding and Alkaline/Surfactant/Polymer Processes as Developed and Applied in the People's Republic of China. J. Pet. Tech. 2006, 58, 84-89.

97. Moffitt, P.D.; Mitchell, J.F. North Burbank Unit Commercial Scale Polymerflood Project-Osage County, Oklahoma (SPE-11560). In Proceedings of SPE Production Operations Symposium, Oklahoma City, OK, USA, 27 February-1 March, 1983.

98. Chaparral Energy Inc., Mid Continent, North Burbank Unit-Osage County, Oklahoma. Available online: http://www.chaparralenergy.com/index.php?page=mid_continent (accessed on 23 August 2010).

99. Pratap, M.; Roy, R.P.; Gupta, R.K.; Singh, D. Field Implementation of Polymer EOR Technique-A Successful Experiment in India (SPE-38872). In Proceedings of SPE Annual Technical Conference and Exhibition, San Antonio, TX, USA, 5-8 October 1997.

100. Tiwari, D.; Marathe, R.V.; Patel, N.K.; Ramachandran, K.P.; Maurya, C.R.; Tewari, P.K. Performance of Polymer Flood in Sanand Field, India-A Case Study (SPE-114878). In Proceedings of SPE Asia Pacific Oil and Gas Conference and Exhibition, Perth, Australia, 20-22 October 2008.

101. Koning, E.J.L.; Mentzer, E.; Heemskerk, J. Evaluation of a Pilot Polymer Flood in the Marmul Field, Oman (SPE-18092). In Proceedings of SPE Annual Technical Conference and Exhibition, Houston, TX, USA, 2-5 October 1988.

102. Mack, J. Special Report: Upstream China-In-depth Gel Shows Promise in Daqing IOR (Improved Oil Recovery) Pilot. Oil Gas J. 2005, 103, 44-47.

103. Chang, H.L.; Sui, X.; Xiao, L.; Guo, Z.; Yao, Y.; Xiao, Y.; Chen, G.; Song, K.; Mack, J.C. Successful Field Pilot of In-Depth Colloidal Dispersion Gel (CDG) Technology in Daqing Oil Field. SPE Reservoir Eval. Eng. 2006, 9, 664-673. 
104. Diaz, D.; Somaruga, C.; Norman, C.; Romero, J. Colloidal Dispersion Gels Improve Oil Recovery in a Heterogeneous Argentina Waterflood (SPE-113320). In Proceedings of SPE/DOE Symposium on Improved Oil Recovery, Tulsa, OK, USA, 20-23 April 2008.

105. Muruaga, E.; Flores, M.; Norman, C.; Romero, J. Combining Bulk Gels and Colloidal Dispersion Gels for Improved Volumetric Sweep Efficiency in a Mature Waterflood (SPE-113334). In Proceedings of SPE/DOE Symposium on Improved Oil Recovery, Tulsa, OK, USA, 20-23 April 2008.

106. Mack, J.C.; Smith, J.E. In-Depth Colloidal Dispersion Gels Improve Oil Recovery Efficiency (SPE-27780). SPE/DOE Improved Oil Recovery Symposium, Tulsa, OK, USA, 17-20 April 1994.

107. Fielding, R.C., Jr.; Gibbons, D.H.; Legrand, F.P. In-Depth Drive Fluid Diversion Using an Evolution of Colloidal Dispersion Gels and New Bulk Gels: An Operational Case History of North Rainbow Ranch Unit (SPE-27773). In Proceedings of SPE/DOE Improved Oil Recovery Symposium, Tulsa, OK, 17-20 April 1994.

108. Frampton, H.; Morgan, J.C.; Cheung, S.K.; Munson, L.; Chang, K.T.; Williams, D. Development of a Novel Waterflood Conformance Control System (SPE-89391). In Proceedings of SPE/DOE Symposium on Improved Oil Recovery, Tulsa, OK, USA, 17-21 April 2004.

109. Puckett, D. BP's Pushing Reservoir Limits Flagship: A Focus on Bright Water. Presented at the ACI Optimising EOR Strategy 2009, London, UK, 11-12 March 2009.

110. Ohms, D.; McLeod, J.; Graff, C.J.; Frampton, H.; Morgan, J.C.; Cheung, S.; Yancey, K.; Chang, K.T. Incremental Oil Success From Waterflood Sweep Improvement in Alaska (SPE-121761). In Proceedings of SPE International Symposium on Oilfield Chemistry, The Woodlands, TX, USA, 20-22 April 2009.

111. Frampton, H.; Denyer, P.; Ohms, D.H.; Husband, M.; Mustoni, J.L. Sweep Improvement from the Lab to the Field. Presented at the 15th European Symposium on Improved Oil Recovery, Paris, France, 27-29 April, 2009.

112. Mustoni, J.L.; Norman, C.A.; Denyer, P. Deep Conformance Control by a Novel Thermally Activated Particle System to Improve Sweep Efficiency in Mature Waterfloods of the San Jorge Basin (SPE-129732). In Proceedings of SPE Improved Oil Recovery Symposium, Tulsa, OK, USA, 24-28 April 2010.

113. Pritchett, J.; Frampton, H.; Brinkman, J.; Cheung, S.; Morgan, J.; Chang, K.T.; Williams, D.; Goodgame, J. Field Application of a New In-Depth Waterflood Conformance Improvement Tool. SPE paper 84897. Presented at the SPE International Improved Oil Recovery Conference (Asia Pacific), Kuala Lumpur, Malaysia, 20-21 October 2003.

114. Spildo, K.; Skauge, A.; Aarra, M.G.; Tweheyo, M.T. A New Polymer Application for North Sea Reservoirs. SPE Reservoir Eval. Eng. 2009, 12, 427-432.

115. Manning, R.K.; Pope, G.A.; Lake, L.W.; Paul, G.W.; Wesson, T.C. A Technical Survey of Polymer Flooding Projects; Report No. DOE/BC/10327-19; U.S. Department of Energy: Tulsa, OK, USA, 1983; p.329.

116. Lowry, P.H.; Ferrell, H.H.; Dauben, D.L. A Review and Statistical Analysis of Micellar-Polymer Field Test Data National Petroleum Technology Office; Report No. DOE/BC/10830-4; U.S. Department of Energy: Tulsa, OK, USA, 1986. 
117. Demin, W.; Jiecheng, C.; Junzheng, W.; Zhenyu, Y.; Yuming, Y.; Hongfu, L. Summary of ASP Pilots in Daqing Oil Field (SPE-57288). In Proceedings of SPE Asia Pacific IOR Conference, Kuala Lumpur, Malaysia, 25-26 October 1999.

118. Hongfu, L.; Guangzhi, L.; Peihui, H.; Zhenyu, Y.; Xiaolin, W.; Chen Guangyu, C.; Dianping, X.; Peiqiang, J. Alkaline/Surfactant/Polymer (ASP) Commercial Flooding Test in Central Xing2 Area of Daqing Oilfield (SPE-84896). In Proceedings of SPE Asia Pacific International Improved Oil Recovery Conference, Kuala Lumpur, Malaysia, 20-21 October 2003.

119. Li, D.; Shi, M.; Wang, D.; Li, Z. Chromatographic Separation of Chemicals in Alkaline Surfactant Polymer Flooding in Reservoir Rocks in the Daqing Oil Field SPE-121598). In Proceedings of SPE International Symposium on Oilfield Chemistry, The Woodlands, TX, USA, 20-22 April 2009.

120. Pu, H.; Xu, Q. An Update and Perspective on Field-Scale Chemical Floods in Daqing Oilfield, China (SPE-118746). In Proceedings of SPE Middle East Oil and Gas Show and Conference, Bahrain, Kingdom of Bahrain, 15-18 March 2009.

121. Qu, Z.; Zhang, Y.; Zhang, X.; Dai, J.A Successful ASP (Alkaline / Surfactant / Polymer) Flooding Pilot in Gudong Oil Field (SPE-39613). In Proceedings of 11th SPE/DOE Improved Oil Recovery Symposium, Tulsa, OK, USA, 19-22 April 1998.

122. Gu, H.; Yang, R.; Guo, S.; Guan, W.; Yue, X.; Pan, Q. Study on Reservoir Engineering: ASP (Alkali, Surfactant, Polymer) Flooding Pilot Test in Karamay Oilfield (SPE-50918). In Proceedings of 6th SPE Oil \& Gas International Conference, Beijing, China, 2-6 November 1998.

123. Qiao, Q.; Gu, H.; Li, D.; Dong, L. The Pilot Test of ASP (Alkaline/Surfactant/Polymer Flooding) Combination Flooding In Karamay Oil Field (SPE-64726). In Proceedings of SPE Oil \& Gas International Conference, Beijing, China, 7-10 November, 2000.

124. Pratap, M.; Gauma, M.S. Field Implementation of Alkaline-Surfactant-Polymer (ASP) Flooding: A Maiden Effort in India (SPE-88455). In Proceedings of SPE Asia Pacific Oil \& Gas Conference, Perth, Australia, 18-20 October 2004.

125. Meyers, J.J.; Pitts, M.J.; Wyatt, K. Alkaline-Surfactant-Polymer Flood of the West Kiehl, Minnelusa Unit (SPE-24144). In Proceedings of SPE/DOE Enhanced Oil Recovery Symposium, Tulsa, OK, USA, 22-24 April 1992.

126. French, T. Evaluation of the Sho-Vel-Tum Alkali-Surfactant-Polymer (ASP) Oil Recovery Project; DOE/SW/45030-1; U.S. Department of Energy: Tulsa, OK, USA, 1999.

127. Vargo, J.; Turner, J.; Vergnani, B.; Pitts, M.J.; Wyatt, K.; Surkalo, H.; Patterson, D. AlkalineSurfactant-Polymer Flooding of the Cambridge Minnelusa Field. SPE Reservoir Eval. Eng. 2000, 3, 552-558.

128. Pitts, M.J.; Dowling, P.; Wyatt, K.; Surkalo, H.; Adams, C. Alkaline-Surfactant-Polymer Flood of the Tanner Field (SPE-100004). In Proceedings of SPE/DOE Symposium on Improved Oil Recovery, Tulsa, OK, USA, 22-26 April 2006.

129. Zhang, J.; Wang, K.; He, F.; Zhang, F. Ultimate Evaluation of the Alkali/Polymer Combination Flooding Pilot Test in Xing Long Tai Oil Field (SPE-57291). In Proceedings of SPE Asia Pacific IOR Conference, Kuala Lumpur, Malaysia, 25-26 October 1999. 
130. Pitts, M.J.; Wyatt, K.; Surkalo, H. Alkaline-Polymer Flooding of David Pool, Lloydminster Alberta (SPE-89386). In Proceedings of SPE/DOE Fourteenth Symposium on IOR, Tulsa, OK, USA, 17-21 April, 2004.

131. Bou-Mikael, S.; Faisal Asmadi, F.; Marwoto, D.; Cease, C. Minas Surfactant Field Trial Tests Two Newly Designed Surfactants with High EOR Potential (SPE-64288). In Proceedings of SPE Asia Pacific Oil and Gas Conference and Exhibition, Brisbane, Australia, 16-18 October 2000.

132. Zargon Energy Trust. Peters Toronto Conference: 16 September 2009. Panel Discussion: WCSB Crude Oil Opportunities. Available online: http://www.zargon.ca/documents/ZargonEnergy TrustSeptember2009PetersPresentationfinal.pdf. (accessed on 24 August 2010).

133. Watkins, C. Chemically enhanced oil recovery stages a comeback. In International News on Fats, Oils and Related Materials; The American Oil Chemists' Society: Boulder, IL, USA, 2009.

134. Fletcher, A.J.P.; Morrison, G.R. Developing a Chemical EOR Pilot Strategy for a Complex, Low Permeability Water Flood (SPE-112793). In Proceedings of SPE/DOE Symposium on Improved Oil Recovery, Tulsa, OK, USA, 20-23 April 2008.

135. Alvarado, V.; Thyne, G.; Murrell, G.R. Screening Strategy for Chemical Enhanced Oil Recovery in Wyoming Basins (SPE-115940). In Proceedings of SPE Annual Technical Conference and Exhibition, Denver, CO, 21-24 September 2008.

136. Costa, A.P.A.; Schiozer, D.J.; Moczydlower, P.; Bedrikovetsky, P. Use of Representative Models to Improve the Decision Making Process of Chemical Flooding in a Mature Field (115442). In Proceedings of SPE Russian Oil and Gas Technical Conference and Exhibition, Moscow, Russia, 28-30 October 2008.

137. Pandey, A.; Beliveau, D.; Suresh Kumar, M.; Pitts, M.J.; Qi, J. Evaluation of Chemical Flood Potential for Mangala Field, Rajasthan, India-Laboratory Experiment Design and Results (IPTC-12636). In Proceedings of International Petroleum Technology Conference, Kuala Lumpur, Malaysia, 3-5 December 2008.

138. Pandey, A. Refinement of Chemical Selection for the Planned ASP Pilot in Mangala FieldAdditional Phase Behaviour and Coreflood Studies (SPE-129046). In Proceedings of SPE Oil and Gas India Conference and Exhibition, Mumbai, India, 20-22 January 2010.

139. Morvan, M.; Degré, G.; Leng, J.; Masselon, C.; Moreau, P.; Bouillot J.; Zaitoun, A. New Viscoelastic Fluid for Chemical EOR (SPE-121675). In Proceedings of SPE International Symposium on Oilfield Chemistry, The Woodlands, TX, USA, 20-22 April 2009.

140. Roshanfekr, M.; Johns, R.T.; Pope, G.; Britton, L.; Linnemeyer, H.; Britton, C.; Vyssotski, A. Effect of Pressure, Temperature, and Solution Gas on Oil Recovery From Surfactant Polymer Floods (SPE125095). In Proceedings of SPE Annual Technical Conference and Exhibition, New Orleans, LA, 4-7 October 2009.

141. Weatherill, A. Surface Development Aspects of Alkali-Surfactant-Polymer (ASP) Flooding (IPTC-13397). In Proceedings of International Petroleum Technology Conference, Doha, Qatar, 7-9 December 2009.

142. Panda, M.N.; Ambrose, J.G.; Beuhler, G.; McGuire, P.L. Optimized EOR Design for the Eileen West End Area, Greater Prudhoe Bay. SPE Reservoir Eval. Eng. 2009, 12, 25-32. 
143. Rathman, M.P.; McGuire, P.L.; Carlson, B.H. Unconventional EOR Program Increases Recovery in Mature WAG Patterns at Prudhoe Bay (SPE-10042). In Proceedings of SPE/DOE Symposium on Improved Oil Recovery, Tulsa, OK, USA, 22-26 April 2006.

144. Shi, W.; Corwith, J.; Bouchard, A.; Bone, R.; Reinbold, E. Kuparuk MWAG Project After 20 Years (SPE-113933). In Proceedings of SPE/DOE Symposium on Improved Oil Recovery, Tulsa, OK, USA, 20-23 April 2008.

145. Redman, R.S. Horizontal Miscible Water Alternating Gas Development of the Alpine Field, Alaska (SPE-76819). In Proceedings of SPE Western Regional/AAPG Pacific Section Joint Meeting, Anchorage, Alaska, 20-22 May 2002.

146. Christensen, J.R.; Stenby, E.H.; Skauge, A. Review of WAG Field Experience. SPE Reservoir Eval. Eng. 2001, 4, 97-106.

147. Wo, S.; Whitman, L.D.; Steidtmann, J.R. Estimates of Potential $\mathrm{CO}_{2}$ Demand for $\mathrm{CO}_{2} \mathrm{EOR}$ in Wyoming Basins (SPE-122921). In Proceedings of SPE Rocky Mountain Petroleum Technology Conference, Denver, CO, USA, 14-16 April 2009.

148. Holtz, M.H. Summary of Sandstone Gulf Coast $\mathrm{CO}_{2}$ EOR Flooding Application and Response (SPE-113368). In Proceedings of SPE/DOE Symposium on Improved Oil Recovery, Tulsa, OK, USA, 20-23 April 2008.

149. Dino, R.; Rocha, P.S.; Sanches, C.; Le Thiez, P. EOR and Storage Activities driven by $\mathrm{CO}_{2}$ in Brazil-Experience from the Buracica and Miranga oil fields performance: Planned Operations. Presented at the 2nd International Symposium: Capture and Geological Storage of $\mathrm{CO}_{2}$, Paris, France, 3-5 October, 2007.

150. Guedes, S. 70\% Recovery Factor: Petrobras Perspective. In Proceedings of Rio Oil \& Gas Exposition and Conference, Rio de Janeiro, Brazil, 15-18 September 2008.

151. Stephenson, D.J.; Graham, A.G.; Luhning, R.W. Mobility Control Experience in the Joffre Viking Miscible $\mathrm{CO}_{2}$ Flood. SPE Reservoir Eng. 1993, 8, 183-188.

152. Bachu, S.; Brulotte, M.; Grobe, M.; Stewart, S. Suitability of the Alberta Subsurface for Carbon-Dioxide Sequestration in Geological Media; Earth Sciences Report 2000-11; Alberta Energy and Utilities Board: Calgary, Canada, March 2000.

153. PTAC. $\mathrm{CO}_{2}$ from Industrial Sources to Commercial Enhanced Oil and Gas Recovery, Petroleum Technology Alliance of Canada (PTAC) $\mathrm{CO}_{2}$ Conference, Calgary, AB, Canada, 1-2 October, 2003.

154. Byfield, M. Husky and PTAC Propose A Game-Changing $\mathrm{CO}_{2}$ EOR Project. Oil Gas Inquirer 2009, January, 5.

155. Novosel, D. Initial Results of WAG $\mathrm{CO}_{2}$ IOR Pilot Project Implementation in Croatia (SPE-97639). In Proceedings of SPE International Improved Oil Recovery Conference in Asia Pacific, Kuala Lumpur, Malaysia, 5-6 December 2005.

156. Novosel, D. Thermodynamic Criteria and Final Results of $\mathrm{WAG} \mathrm{CO}_{2}$ Injection in a Pilot Project in Croatia (SPE-119747). In Proceedings of SPE Middle East Oil and Gas Show and Conference, Bahrain, Kingdom of Bahrain, 15-18 March 2009.

157. Domitrović, D.; Sunjerga, S.; Jelić-Balta, J. Numerical Simulation of Tertiary $\mathrm{CO}_{2}$ Injection at Ivanić Oil Field, Croatia (SPE-89361). In Proceedings of SPE/DOE Symposium on Improved Oil Recovery, Tulsa, OK, USA, 17-21 April 2004. 
158. Doleschall, S.; Szittar, A.; Udvardi, G. Review of the 30 Years' Experience of the $\mathrm{CO}_{2}$ Imported Oil Recovery Projects in Hungary (SPE-22362). In Proceedings of International Meeting on Petroleum Engineering, Beijing, China, 24-27 March 1992.

159. Remenyi, I.; Szittar, A.; Udvardi, G. $\mathrm{CO}_{2}$ IOR in the Szank Field Using $\mathrm{CO}_{2}$ from Sweetening Plant. In Proceedings of 8th European Symposium on Improved Oil Recovery, Vienna, Austria, 15 May, 1995.

160. Mohammed-Singh, L.J.; Singhal, A.K. Lessons From Trinidad's $\mathrm{CO}_{2}$ Immiscible Pilot Projects 1973-2003 (SPE-89364). In Proceedings of SPE/DOE Symposium on Improved Oil Recovery, Tulsa, OK, USA, 17-21 April 2004.

161. Muro, H.G.; Campos, S.B.; Alcazar, L.O.; Rodríguez, J.A. Quebrache--A Natural $\mathrm{CO}_{2}$ Reservoir: A New Source for EOR Projects in Mexico (SPE-107445). In Proceedings of Latin American \& Caribbean Petroleum Engineering Conference, Buenos Aires, Argentina, 15-18 April 2007.

162. Bauer, M. Near-Term Opportunities and Emerging Economies: A view from Mexico. Presentation at the G8/IEA/CSFL Workshop on Near Term Opportunities for Carbon Capture and Storage, San Francisco, CA, USA, 22-23 August 2006.

163. Kulkarni, M.M.; Chen, H.L.; Brummert, A.C. $\mathrm{CO}_{2}$ IOR Evaluation for the U.S. Rocky Mountain Assets (SPE-113297). In Proceedings of SPE/DOE Symposium on Improved Oil Recovery, Tulsa, OK, USA, 20-23 April 2008.

164. Senocak, D.; Pennell, S.P.; Gibson, C.E.; Hughes, R.G. Effective Use of Heterogeneity Measures in the Evaluation of a Mature $\mathrm{CO}_{2}$ Flood (SPE-113977). In Proceedings of SPE/DOE Symposium on Improved Oil Recovery, Tulsa, OK, USA, 20-23 April 2008.

165. Manrique, E. Enhanced Oil Recovery (EOR): Trends, Risks, and Rewards. Presented at the ACI Optimising EOR Strategy 2009, London, UK, 11-12 March, 2009.

166. Clancy, J.P.; Philcox, J.E.; Watt, J.; Gilchrist, R.E. Cases and Economics for Improved Oil and Gas Recovery using Nitrogen. In Proceedings of 36th Annual Technical Meeting, Edmonton, Canada, 2-5 June 1985; Paper No. 85-36-2.

167. Levine, S.; Sigmon, R.; Douglas, S. Yates Field-Super Giant of the Permian Basin. Houston Geol. Soc. Bull. 2002, 45, 39-45, 47-49, 51.

168. Button, P.; Peterson, C. Enhanced Gravity Drainage through Immiscible $\mathrm{CO}_{2}$ Injection in the Yates Field (TX). In Proceedings of 10th Annual $\mathrm{CO}_{2}$ Flooding Conference, Midland, TX, USA, December 2004.

169. Dehghani, K.; Ehrlich, R. Evaluation of steam injection process in light oil reservoirs (SPE49016). In Proceedings of SPE Annual Technical Conference, New Orleans, LA, USA, 27-30 September 1998.

170. Snell, J.S.; Wadleigh, E.E.; Tilden, J. Fracture Characterization a Key Factor in Yates Steam Pilot Design and Implementation (SPE-59060). In Proceedings of SPE International Petroleum Conference and Exhibition, Villahermosa, Mexico, 1-3 February 2000.

171. Yang, H.D.; Wadleigh, E.E. Dilute Surfactant IOR-Design Improvement for Massive, Fractured Carbonate Applications (SPE-59009). In Proceedings of 2000 SPE International Petroleum Conference and Exhibition in Mexico, Villahermosa, Mexico, February 2000.

172. Chen, H.L.; Lucas, L.R.; Nogaret, L.A.D.; Yang, H.D.; Kenyon, D.E. Laboratory Monitoring of Surfactant Imbibition Using Computerized Tomography (SPE-59006). In Proceedings of 2000 
SPE International Petroleum Conference and Exhibition in Mexico, Villahermosa, Mexico, February 2000.

173. Chen, H.L.; Lucas, L.R.; Nogaret, L.A.D.; Yang, H.D.; Kenyon, D.E. Laboratory Monitoring of Surfactant Imbibition Using Computerized Tomography. SPE Reservoir Eng. 2001, February, $16-25$.

174. Campanella, J.D.; Wadleigh E.E.; Gilman J.R. Flow Characterization-Critical for Efficiency of Field Operations and IOR (SPE-58996). In Proceedings of SPE International Petroleum Conference and Exhibition in Mexico, Villahermosa, Mexico, February 2000.

175. Alvarez, J.M.; Sawatzky, R.P.; Forster, L.M.; Coates, R.M. Alberta's Bitumen Carbonate Reservoirs-Moving Forward with Advanced R\&D (Paper 2008-467). In Proceedings of World Heavy Oil Congress, Edmonton, Canada, 10-12 March 2008.

176. Sahuquet, B.C.; Ferrier, J.J. Steam-Drive Pilot in a Fractured Carbonated Reservoir: Lacq Superieur Field. J. Pet. Tech. 1982, 34, 873-880.

177. Sahuquet, B.C.; Spreux, A.M.; Corre, B.; Guittard, M.P. Steam Injection in a Low-Permeability Reservoir Through a Horizontal Well in Lacq Superieur Field (SPE-20526). In Proceedings of SPE Annual Technical Conference and Exhibition, New Orleans, LA, USA, 23-26 September 1990.

178. Nakamura, S.; Sarma, H.K.; Umucu, T.; Issever, K.; Kanemitsu, M.A. Critical Evaluation of a Steamflood Pilot in a Deep Heavy Carbonate Reservoir in Ikiztepe Field, Turkey (SPE-30727). In Proceedings of SPE Annual Technical Conference and Exhibition, Dallas, TX, USA, 22-25 October 1995.

179. Zhou, Y.; Lin, Y.; Chen, G. Steam Stimulation Pilot in the Cao-20 Fracture Limestone with Extra Heavy Oil. (Paper 1998-131). In Proceedings of 7th UNITAR International Conference on Heavy Crude and Tar Sands, Beijing, China, 27-30 October 1998.

180. Macaulay, R.C.; Krafft, J.M.; Hartemink, M.; Escovedo, B. Design of a Steam Pilot In A Fractured Carbonate Reservoir-Qarn Alam Field, Oman (SPE-30300). In Proceedings of SPE International Heavy Oil Symposium, Calgary, AB, Canada, 19-21 June 1995.

181. Penney, R.; Moosa, R.; Shahin, G.; Hadhrami, F.; Kok, A.; Engen, G.; Van Ravesteijn, O.; Rawnsley, K.; Kharusi, B. Steam Injection in Fractured Carbonate Reservoirs: Starting a New Trend in EOR (IPTC-10727). In Proceedings of International Petroleum Technology Conference, Doha, Qatar, 21-23 November 2005.

182. Penney, R.; Baqi Al Lawati, S.; Hinai, R.; Van Ravesteijn, O.; Rawnsley, K.; Putra, P.; Geneau, M.; Ikwumonu, A.; Habsi, M.; Harrasy, H. First Full Field Steam Injection in a Fractured Carbonate at Qarn Alam, Oman (SPE-105406). In Proceedings of SPE Middle East Oil and Gas Show and Conference, Bahrain, Kingdom of Bahrain, 11-14 March 2007.

183. Waheed, A.; El-Assal, H.; Negm, E.; Sanad, M.; Sanad, O.; Tuchscherer, G.; Sayed, M. Practical Methods to Optimizing Production in a Heavy-Oil Carbonate Reservoir: Case Study From Issaran Field, Eastern Desert, Egypt (SPE-69730). In Proceedings of SPE International Thermal Operations and Heavy Oil Symposium, Margarita Island, Venezuela, 12-14 March 2001.

184. Buza, J.W. An Overview of Heavy and Extra Heavy Oil Carbonate Reservoirs in the Middle East (IPTC-12426). In Proceedings of International Petroleum Technology Conference, Kuala Lumpur, Malaysia, 3-5 December 2008. 
185. Barge, D.; Al-Yami, F.; Uphold, D.; Zahedi, A.; Deemer, A.; Carreras, P.E. Steamflood Piloting the Wafra Field Eocene Reservoir in the Partitioned Neutral Zone, Between Saudi Arabia and Kuwait (SPE-120205). In Proceedings of SPE Middle East Oil and Gas Show and Conference, Bahrain, Kingdom of Bahrain, 15-18 March 2009.

186. Sedaee, B.; Rashidi, F. Application of the SAGD to an Iranian Carbonate Heavy-Oil Reservoir (SPE-100533). In Proceedings of SPE Western Regional/AAPG Pacific Section/GSA Cordilleran Section Joint Meeting, Anchorage, Alaska, 8-10 May 2006.

187. Shafiei, A.; Dusseault, M.B.; Memarian, H.; Samimi Sahed, B. Production Technology Selection for Iranian Naturally Fractured Heavy Oil Reservoirs (Paper 2007-145). In Proceedings of Petroleum Society's 8th Canadian International Petroleum Conference (58th Annual Technical Meeting), Calgary, AB, Canada, 12-14 June 2007.

188. Gutiérrez, D.; Miller, R.J.; Taylor, A.R.; Thies, B.P.; Kumar, V.K. Buffalo Field High-Pressure Air Injection Projects: Technical Performance and Operational Challenges (SPE-113254). In Proceedings of SPE/DOE Symposium on Improved Oil Recovery, Tulsa, OK, USA, 20-23 April 2008.

189. Kumar, V.K.; Gutierrez, D.; Moore, R.G.; Mehta, S.A. Air Injection and Waterflood Performance Comparison of Two Adjacent Units in the Buffalo Field (SPE-104479). SPE Reservoir Eval. Eng. 2008, October, 848-857.

190. Moore, R.G.; Mehta, S.A.; Ursenbach, M.G. A Guide to High Pressure Air Injection (HPAI) Based Oil Recovery (SPE-75207). In Proceedings of SPE/DOE Improved Oil Recovery Symposium, Tulsa, Oklahoma, 13-17 April 2002.

191. Gutiérrez, D.; Taylor, A.R.; Kumar, V.K.; Ursenbach, M.G.; Moore, R.G.; Mehta, S.A. Recovery Factors in High-Pressure Air Injection Projects Revisited (SPE-108429). SPE Reservoir Eval. Eng. 2008, 11, 1097-1106.

192. Rodríguez, F.; Christopher, C.A. Overview of Air Injection Potential for PEMEX (Paper No. 89612). In Proceedings of AAPG International Conference, Cancun, Mexico, 24-27 October 2004.

193. Al-Hashim, H.S.; Obiora, V.; Al-Yousef, H.Y.; Fernandez, F.; Nofal, W. Alkaline Surfactant Polymer Formulation for Saudi Arabian Carbonate Reservoirs (SPE-35353). In Proceedings of SPE/DOE Improved Oil Recovery Symposium, Tulsa, OK, USA, 21-24 April 1996.

194. Bortolotti, V.; Gottardi, G.; Macini, P.; Srisuriyachai, F. Intermittent Alkali Flooding in Vertical Carbonate Reservoirs (SPE-121832). In Proceedings of EUROPEC/EAGE Conference and Exhibition, Amsterdam, The Netherlands, 8-11 June 2009.

195. Bortolotti, V.; Macini, P.; Srisuriyachai, F. Laboratory Evaluation of Alkali and AlkaliSurfactant-Polymer Flooding Combined With Intermittent Flow in Carbonatic Rocks (SPE122499). In Proceedings of Asia Pacific Oil and Gas Conference \& Exhibition, Jakarta, Indonesia, 4-6 August 2009.

196. Bortolotti, V.; Macini, P.; Mesini, E.; Srisuriyachai, F. Combined Spatially Resolved and Nonresolved 1H-NMR Relaxation Analysis to Assess and Monitor Wettability Reversal in Carbonate Rocks (IPTC-13443). In Proceedings of International Petroleum Technology Conference, Doha, Qatar, 7-9 December 2009. 
197. Zubari H.K.; Sivakumar, V.C.B. Single Well Tests to Determine the Efficiency of AlkalineSurfactant Injection in a Highly Oil-Wet Limestone Reservoir (SPE-81464). In Proceedings of 13th SPE Middle East Oil Show \& Conference, Bahrain, Kingdom of Bahrain, 5-8 April 2003.

198. Najafabadi, N.F.; Delshad, M.; Sepehrnoori, K.; Nguyen, Q.P.; Zhang, J. Chemical Flooding of Fractured Carbonates Using Wettability Modifiers (SPE-113369). In Proceedings of SPE/DOE Symposium on Improved Oil Recovery, Tulsa, OK, USA, 20-23 April 2008.

199. Tabary, R.; Fornari, A.; Bazin, B.; Bourbiaux, B.; Dalmazzone, C. Improved Oil Recovery With Chemicals in Fractured Carbonate Formations (SPE-121668). SPE International Symposium on Oilfield Chemistry, The Woodlands, TX, USA, 20-22 April 2009.

200. Webb, K.J.; Black, C.J.J.; Tjetland, G.A. Laboratory Study Investigating Methods for Improving Oil Recovery in Carbonates (IPTC-10506). In Proceedings of International Petroleum Technology Conference, Doha, Qatar, 21-23 November 2005.

201. Haugen, Å.; Fernø, M.A.; Graue, A. Numerical Simulation and Sensitivity Analysis of In-situ Fluid Flow in MRI Laboratory Waterfloods of Fractured Carbonate Rocks at Different Wettabilities (SPE-116145). In Proceedings of SPE Annual Technical Conference and Exhibition, Denver, CO, USA, 21-24 September 2008.

202. Delshad, M.; Najafabadi, N.F.; Sepehrnoori, K. Scale Up Methodology for Wettability Modification in Fractured Carbonates (SPE-118915). In Proceedings of SPE Reservoir Simulation Symposium, The Woodlands, TX, USA, 2-4 February 2009.

203. Mohanty, K.K. Dilute Surfactant Methods for Carbonate Formations: Final Report; Report No. DE-FC26-02NT 15322; Report for U.S. Department of Energy: Washington, DC, USA, February, 2006.

204. Adibhatia, B.; Mohanty, K.K. Simulation of Surfactant-Aided Gravity Drainage in Fractured Carbonates (SPE-106601). In Proceedings of SPE Reservoir Simulation Symposium, Houston, TX, USA, 26-28 February 2007.

205. Al-Dhafeeri, A.M.; Nasr-El-Din, H.A.; Al-Mubarak, H.K.; Al-Ghamdi, J. Gas Shut-off Treatment in Oil Carbonate Reservoirs in Saudi Arabia (SPE-114323). In Proceedings of SPE Annual Technical Conference and Exhibition, Denver, CO, USA, 21-24 September 2008.

206. Kumar, A.; Al-Ajmi, M.F.; Al-Anzi, E.; Clark, R.A.; Khater, M.; Lantz, J. Water Shut off Techniques to Combat Premature Water Break through in Mauddud Carbonate Reservoir-An Efficacy Analysis (IPTC-11713). In Proceedings of International Petroleum Technology Conference, Dubai, UAE, 46 December 2007.

207. Al-Taq, A.A.; Nasr-El-Din, H.A.; Beresky, J.K.; Naimi, K.M.; Sierra, L.; Eoff, L. Simultaneous Acid Diversion and Water Control in Carbonate Reservoirs: A Case History from Saudi Arabia (SPE-106951). SPE Reservoir Eval. Eng. 2008, 11, 882-891.

208. Smith, D.D.; Giraud, M.J.; Kemp, C.C.; McBee, M.; Taitano, J.A.; Winfield, M.S.; Portwood, J. T.; Everett, D.M. The Succesful Evolution of Anton Irish Conformance Efforts (SPE-103044). In Proceedings of SPE Annual Technical Conference and Exhibition, San Antonio, TX, USA, 24-27 September 2006.

209. Portwood, J.T. The Kansas Arbuckle Formation: Performance Evaluation and Lessons Learned From More Than 200 Polymer-Gel Water-Shutoff Treatments (SPE-94096). In Proceedings of SPE Production Operations Symposium, Oklahoma City, OK, USA, 16-19 April 2005. 
210. Sengupta, T.K.; Singh, R.; Avtar, R.; Singh, K. Successful Gas Shut Off Using Latest Gel Technology In An Indian Offshore Carbonate Field-A Case Study (SPE-72118). In Proceedings of SPE Asia Pacific Improved Oil Recovery Conference, Kuala Lumpur, Malaysia, 6-9 October 2001.

211. Hirasaki, G.J.; Miller, C.A.; Pope, G.A. Surfactant Based Enhanced Oil Recovery and Foam Mobility Control-3rd Annual \& Final Technical Report. Report No. DE-FC26-03NT15406. Rice University and U.S. Department of Energy: Houston, TX, USA, July 2006.

212. Lawrence, J.J.; Maer, N.K.; Stern, D.; Corwin, L.W.; Idol, W.K. Jay Nitrogen Tertiary Recovery Study: Managing a Mature Field (SPE-78527). In Proceedings of Abu Dhabi International Petroleum Exhibition and Conference, Abu Dhabi, UAE, 13-16 October 2002.

213. FORM 8-K: LL\&E ROYALTY TRUST-LRT (February 9, 2009). Available online: http://google.brand.edgar-online.com/EFX_dll/EDGARpro.dll?FetchFilingHTML1?ID=6392338 $\&$ SessionID=rLklHFq_OCp6n47 (accessed on 24 August 2010).

214. Sánchez, J.L; Astudillo, A.; Rodríguez, F.; Morales, J.; Rodríguez, A. Nitrogen Injection in the Cantarell Complex: Results After Four Years of Operation (SPE-97385). In Proceedings of SPE Latin American and Caribbean Petroleum Engineering Conference, Rio de Janeiro, Brazil, 20-23 June, 2005.

215. Mungan, N. Enhanced Oil Recovery with High Pressure Nitrogen Injection (SPE-62547). In Proceedings of SPE/AAPG Western Regional Meeting, Long Beach, CA, USA, 19-22 June 2000.

216. Linderman, J.; Al-Jenaibi, F.; Ghori, S.; Putney, K.; Lawrence, J.; Gallet, M.; Hohensee, K. Substituting Nitrogen for Hydrocarbon Gas in a Gas Cycling Project (SPE-117952). In Proceedings of Abu Dhabi International Petroleum Exhibition and Conference, Abu Dhabi, UAE, 3-6 November 2008.

217. Stalkup, F.I., Jr. Status of Miscible Displacement. J. Pet. Tech. 1983, 35, 815-826.

218. Al-Bahar, M.A.; Merrill, R.; Peake, W.; Reza Oskui, M.J. Evaluation of IOR Potential within Kuwait (SPE-88716). In Proceedings of Abu Dhabi International Conference and Exhibition, Abu Dhabi, UAE, 10-13 October 2004.

219. Edwards, K.A.; Anderson, B.; Reavie, B. Horizontal Injectors Rejuvenate Mature Miscible Flood-South Swan Hills Field. SPE Reservoir Eval. Eng. 2002, 5, 174-182.

220. El Mahdi, A.; Ayoub, M.; Daif-Allah, S.; Negahban, S.; Ribeiro, M.; Bahamaish, J. An Integrated Approach for a Full-Field, Optimized Development of a Carbonate Reservoir on a Shallow Marine Environment, Abu Dhabi (SPE-105416). In Proceedings of SPE Middle East Oil and Gas Show and Conference, Bahrain, 11-14 March 2007.

221. Gomes, J.S.; Ribeiro, M.T.; Fouchard, P.; Twombley, B.N.; Negahban, S.; Al-Baker, S. Geological Modeling of a Tight Carbonate Reservoir for Improved Reservoir Management of a Miscible WAG Injection Project, Abu Dhabi, U.A.E. (SPE-78529). In Proceedings of Abu Dhabi International Petroleum Exhibition and Conference, Abu Dhabi, UAE, 13-16 October 2002.

222. Mijnssen, F.C.J.; Davies, A.H.; Grondin, K.; Keating, J.; Hsu, C.F.; Amthor, J. Bringing Al Huwaisah's Volume to Value (SPE-84285). In Proceedings of SPE Annual Technical Conference and Exhibition, Denver, CO, USA, 5-8 October, 2003. 
223. Schneider, C.; Shi, W.A Miscible WAG Project Using Horizontal Wells in a Mature Offshore Carbonate Middle East Reservoir (SPE-93606). In Proceedings of SPE Middle East Oil and Gas Show and Conference, Kingdom of Bahrain, 12-15 March, 2005.

224. Boge, R.; Lien, S.K.; Gjesdal, A.; Hansen, A.G. Turning a North Sea Oil Giant Into a Gas Field-Depressurization of The Statfjord Field (SPE-96403), Offshore Europe: Aberdeen, U.K., 6-9 September 2005.

225. Blanksby, J.; Hicking, S.; Milne, W. Deployment of High Horsepower ESPs to Extend Brent Field Life (SPE-96797); Offshore Europe: Aberdeen, U.K., 6-9 September 2005.

226. Chekani, M.; Mackay, E.J. Impact on Scale Management of the Engineered Depressurization of Waterflooded Reservoirs: Risk Assessment Principles and Case Study. SPE Prod. Oper. 2006, 21, 174-181.

227. Asghari, K.; Dong, M.; Shire, J.; Coleridge, T.; Nagrampa, J.; Grassick, J. Development of a Correlation Between Performance of $\mathrm{CO}_{2}$ Flooding and the Past Performance of Waterflooding in Weyburn Oil Field. SPE Prod. Oper. 2007, 22, 260-264.

228. Karaoguz, O.K.; Topguder, N.N.; Lane, R.H.; Kalfa U.; Celebioglu, D. Improved Sweep in Bati Raman Heavy-Oil $\mathrm{CO}_{2}$ Flood: Bullhead Flowing Gel Treatments Plug Natural Fractures. SPE Reservoir Eval. Eng. 2007, 10, 164-175.

229. Louie, J. Operating Experience from $\mathrm{CO}_{2}$ Miscible Floods Provides Design Guidelines for $\mathrm{CO}_{2}$ Sequestration; Hatch Energy: Oakville, Canada, February 2009.

230. Sahin, S.; Kalfa, U.; Celebioglu, D. Bati Raman Field Immiscible $\mathrm{CO}_{2}$ Application-Status Quo and Future Plans (SPE-106575). SPE Reservoir Eval. Eng. 2008, 11, 778-791.

231. Reuters India. Aramco to inject $\mathrm{CO}_{2}$ into biggest oilfield by 2012. Reuters, 15 February, 2010. Available online: http://in.reuters.com/article/oilRpt/idINLDE61E0TW20100215(accessed on 23 August 2010).

232. Alsharif, A. Aramco to inject $\mathrm{CO}_{2}$ into world's biggest oilfield in 2012. Arabian Business, 15 February, 2010. Available online: http://www.arabianbusiness.com/581615-aramco-to-injectco2-into-worlds-biggest-oilfield-in-2012(accessed on 23 August 2010).

233. Hamilton, G. Strategies for $\mathrm{CO}_{2}$ Reductions in the U.S. Enhanced Oil Recovery Production Segment: Utilizing Energy Efficiency as the First Step (SPE-121003). In Proceedings of SPE Americas E\&P Environmental and Safety Conference, San Antonio, TX, USA, 23-25 March, 2009.

234. Bachu, S.; Shaw, J.C. $\mathrm{CO}_{2}$ storage in oil and gas reservoirs in Western Canada: Effect of aquifers, potential for $\mathrm{CO}_{2}$-flood enhanced oil recovery and practical capacity. In Proceedings of 7th International Conference on Greenhouse Gas Control Technologies, Vancouver, Canada, 5-9 September 2004.

235. Hughes, D.S. Relative Merits of $\mathrm{CO}_{2}$ Geological Storage Options. In Proceedings of Devex Conference, Aberdeen, UK, 15 May 2008.

236. Manrique, E.; Araya, A. Capture and Geologic Sequestration-What it is and its Implications. CPSA J. 2008, 6, 29-34.

237. Algharaib, M.; Al-Soof, N.A. Economical Modeling of $\mathrm{CO}_{2}$ Capturing and Storage Projects (SPE-120815). In Proceedings of SPE Saudi Arabia Section Technical Symposium, Al-Khobar, Saudi Arabia, 10-12 May 2008. 
238. Ghomian, Y.; Urun, M.; Pope, G.A.; Sepehrnoori, K. Investigation of Economic Incentives for $\mathrm{CO}_{2}$ Sequestration (SPE-116717). In Proceedings of SPE Annual Technical Conference and Exhibition, Denver, CO, USA, 21-24 September, 2008.

239. Imbus, S.; Orr, F.M.; Kuuskraa, V.A.; Kheshgi, H.; Bennaceur, K.; Gupta, N.; Rigg, A.; Hovorka, S.; Myer L.; Benson, S. Critical Issues in $\mathrm{CO}_{2}$ Capture and Storage: Findings of the SPE Advanced Technology Workshop (ATW) on Carbon Sequestration (SPE-102968). In Proceedings of SPE Annual Technical Conference and Exhibition, San Antonio, TX, USA, 24-27 September, 2006.

240. Xie, X.; Economides, M.J. The Impact of Carbon Geological Sequestration (SPE-120333). In Proceedings of SPE Americas E\&P Environmental and Safety Conference, San Antonio, TX, 23-25 March, 2009.

241. Zeidouni, M.; Moore, M.; Keith, D. Guidelines for a Regulatory Framework to Accommodate Geological Storage of $\mathrm{CO}_{2}$ in Alberta (SPE-121000). In Proceedings of SPE Americas E\&P Environmental and Safety Conference, San Antonio, TX, USA, 23-25 March, 2009.

242. MSN Money. Energy: Light Sweet Crude Oil. Available online: http://moneycentral. msn.com/investor/market/commodities.aspx(accessed on 23 August 2010).

243. Point Carbon. EUA OTC Assessment (EUR/t), Point Carbon. Available online: http://www.pointcarbon.com/(accessed on 23 August 2010).

244. x-rates.com. Exchange Rates. Available online: http://www.x-rates.com/(accessed on 23 August 2010).

245. Point Carbon. Carbon A-Z - glossary of keywords. Available online: http://www.pointcarbon. com/1.266906\#E (accessed on 23 August 2010).

246. Longworth, H.L.; Dunn, G.C.; Semchuck, M. Underground Disposal of Acid Gas in Alberta, Canada: Regulatory Concerns and Case Histories (SPE-35584). In Proceedings of SPE Gas Technology Symposium, Calgary, AB, Canada, 28 April-1 May 1996.

247. Abou-Sayed, A.S.; Summers, C.; Zaki, K. An Assessment of Engineering, Economical and Environmental Drivers of Sour-Gas Management by Injection (SPE-97628). In Proceedings of SPE International Improved Oil Recovery Conference in Asia Pacific, Kuala Lumpur, Malaysia, 5-6 December 2005.

248. O'Dell, M.; Soek, H.; van Rossem, S. Achieving the Vision in the Harweel Cluster, South Oman (SPE-102389). In Proceedings of SPE Annual Technical Conference and Exhibition, San Antonio, TX, USA, 24-27 September 2006.

249. Morel, D.; Labasties, A.; Jouenne, S.; Nahas, E. Feasibility Study for EOR by Polymer Injection in Deep Offshore Fields (IPTC-11800). In Proceedings of International Petroleum Technology Conference, Dubai, UAE., 4-6 December 2007.

250. Oliveira, C.A.P.; Beltrão, R.L.C.; Ribeiro, G.J.J. Albacora Field Development (SPE 19224); Offshore Europe: Aberdeen, UK, 5-8 September, 1989.

251. Pereira de Oliveira, C.A.; Guimarães Dias, M.A. Albacora, a Deep Giant Development (SPE21147). In Proceedings of SPE Latin American Petroleum Engineering Conference, Rio de Janeiro, Brazil,, 14-19 October 1990.

252. Barroso, A.S.; Mihaguti, M.; Romeu, R.K.; Bruhn, C.H.L.; Johann, P.R.S., Sombra, C.L.; Sarzenski, D.; Cortez, M.M.M.; Lara, A.Q.; Sourza, O.G. Developments in Reservoir 
Characterization Applied to the Albacora Field (Namorado Sandstone), Campos Basin, Offshore Brazil (OTC-8878). In Proceedings of Offshore Technology Conference, Houston, TX, USA, 4-7 May 1998.

253. Bonet, L.; Romeu, R.K.; Barroso, A.S.; Sombra, C.L.; Cortez, M.M.M., Almeida, S.R.; Schwerdesky, G; Mihaguti, M.K.; Sarzenski, D. Flow Simulation Study of the Namorado Sandstone (Albacora Field, offshore Brazil) Accounting for Scaling of Petrophysical Properties (SPE-53986). In Proceedings of SPE Latin American and Caribbean Petroleum Engineering Conference, Caracas, Venezuela, 21-23 April, 1999.

254. De Macedo, R.A.V.; Asrilhant, B. Marlim Field Development: A Challenge in Deepwaters (SPE21148). In Proceedings of SPE Latin American Petroleum Engineering Conference, Rio de Janeiro, Brazil,, 14-19 October 1990.

255. Capeleiro Pinto, A.C.; Branco, C.C.M.; de Matos, J.S.; S. da Silva Guedes, P.M.V.; Pedroso, C., Jr.; Decnop Coelho, A.C.; Ceciliano, M.M. Offshore Heavy Oil in Campos Basin: The Petrobras Experience (OTC-15283). In Proceedings of 2003 Offshore Technology Conference, Houston, TX, USA, 5-8 May 2003.

256. McJannet, G.S. General Overview of the Elk Hills Field (SPE-35670). $66^{\text {th }}$ Annual Western Regional Meeting, Anchorage, Alaska, 22-24 May, 1996.

257. O’Brien, C.P. Residual Oil Characterization for a California Turbidite (SPE-93326). In Proceedings of SPE Western Regional Meeting, Irvine, CA, USA, 30 March-1 April, 2005.

258. Harrigal, R.L.; Clayton, C.A. Comparison of Conventional Cyclic Steaming and Steamflooding in a Massive Dipping, Midway Sunset Field Reservoir (SPE/DOE-24197). In Proceedings of SPE/DOE Eight Symposium on Enhanced Oil Recovery, Tulsa, OK, USA, 22-24 April 1992.

259. Turan, H.; Skinner, R.; Brand, P.; Macdonald, C.; Grinestaff, G.; Trythall, R. Forties $\mathrm{CO}_{2}$ IOR Evaluation Integrating Finite Difference and Streamline Simulation Techniques (SPE-78298). In Proceedings of SPE $13^{\text {th }}$ European Petroleum Conference, Aberdeen, Scotland, UK, 29-31 October 2002.

260. Bondor, P.L.; Hite, J.R.; Avasthi, S.M. Planning EOR Projects in Offshore Oil Fields (SPE94637). In Proceedings of SPE Latin American and Caribbean Petroleum Engineering Conference, Rio de Janeiro, Brazil, 20-23 June, 2005.

261. ORME. EOR Offshore: Going Too Far? Oil Review Middle East: London, UK, 2009.

262. Awan, A.R.; Teigland, R.; Kleppe, J.A Survey of North Sea Enhanced-Oil-Recovery Projects Initiated During the Years 1975 to 2005. SPE Reservoir Eval. Eng. 2008, 11, 497-512.

263. Jayasekera, A.J.; Goodyear, S.G. Improved Hydrocarbon Recovery in the United Kingdom Continental Shelf: Past, Present and Future (SPE-75171). In Proceedings of SPE/DOE Improved Oil Recovery Symposium, Tulsa, OK, USA, 13-17 April 2002.

264. Jethwa, D.J.; Rothkopf, B.W.; Paulson, C.I. Successful Miscible Gas Injection in a Mature U.K. North Sea Field (SPE-62990). In Proceedings of SPE Annual Technical Conference and Exhibition, Dallas, TX, USA, 1-4 October 2000.

265. Talukdar, S.; Instefjord, R. Reservoir Management of the Gullfaks Main Field (SPE-113260). In Proceedings of EUROPEC/EAGE Conference and Exhibition, Rome, Italy, 9-12 June 2008. 
266. Hamdan, M.K.; Darman, N.; Hussain, D.; Ibrahim, Z. Enhanced Oil Recovery in Malaysia: Making It a Reality (SPE-93329). In Proceedings of PE Asia Pacific Oil and Gas Conference and Exhibition, Jakarta, Indonesia, 5-7 April 2005.

267. Nadeson, G.; Anua, N.A.B.; Singhal, A.; Ibrahim, R.B. Water-Alternating-Gas (WAG) Pilot Implementation, A First EOR Development Project in Dulang Field, Offshore Peninsular Malaysia (SPE-88499). In Proceedings of SPE Asia Pacific Oil and Gas Conference and Exhibition, Perth, Australia, 18-20 October 2004.

268. Samsudin, Y.; Darman, N.; Husain, D.; Hamdan, M.K. Enhanced Oil Recovery in Malaysia: Making It a Reality (Part II) (SPE-95931). In Proceedings of SPE International Improved Oil Recovery Conference in Asia Pacific, Kuala Lumpur, Malaysia, 5-6 December 2005.

269. Selamat, S.; Teletzke, G.F.; Patel, P.D.; Darman, N.; Suhaimi, M.A. EOR: The New Frontier in the Malay Basin Development (IPTC-12805). In Proceedings of International Petroleum Technology Conference, Kuala Lumpur, Malaysia, 3-5 December 2008.

270. Sudirman, S.B.; Samsudin, Y.B.; Darman, N.H. Planning for Regional EOR Pilot for Baram Delta, Offshore Sarawak, Malaysia: Case Study, Lesson Learnt and Way Forward (SPE-109220). In Proceedings of Asia Pacific Oil and Gas Conference and Exhibition, Jakarta, Indonesia, 30 October-1 November 2007.

271. Harun, A.F.; Blanchard, T.J.; Erdogmus, M. Managing Hydrate Risks for a Black Oil Long Subsea Tie-Back When Water Cut Predictions Exceed Original Design (SPE-111138). In Proceedings of SPE North Africa Technical Conference \& Exhibition, Marrakech, Morocco, 12-14 March 2008.

272. Liu, B.; Dessenberger, R.; McMillen, K.; Lach, J.; Kelkar, M. Water-Flooding Incremental Oil Recovery Study in Middle Miocene to Paleocene Reservoirs, Deep-Water Gulf of Mexico (SPE115669). In Proceedings of SPE Asia Pacific Oil and Gas Conference and Exhibition, Perth, Australia, 20-22 October 2008.

273. Mineral Management Services. Reserves vs. Secondary Recovery in GOM; Mineral Management Services: Houston, TX, USA, 2005.

274. Close, F.; McCavitt, B.; Smith, B. Deepwater Gulf of Mexico Development Challenges Overview (SPE-113011). In Proceedings of SPE North Africa Technical Conference \& Exhibition, Marrakech, Morocco, 12-14 March 2008.

275. Iledare, O.O. Profitability of Deepwater Petroleum Leases: Empirical Evidence From the U.S. Gulf of Mexico Offshore Region (SPE-116602). In Proceedings of SPE Annual Technical Conference and Exhibition, Denver, CO, USA, 21-24 September 2008.

276. Poll, P.; Zou, J.; Chianis, J. Contemporary Challenges and Solutions for Post-Katrina Gulf of Mexico Spar Design (OTC-20238). In Proceedings of Offshore Technology Conference, Houston, TX, USA, 4-7 May 2009.

277. Watson, C.C., Jr.; Johnson, M.E. Real-Time Prediction of Shut-in Production from Hurricanes in the Gulf of Mexico (SPE-102374). In Proceedings of SPE Annual Technical Conference and Exhibition, San Antonio, TX, USA, 24-27 September 2006.

278. Cruz, L.; Sheridan, J.; Aguirre, E.; Celis, E.; García-Hernandez, J. Relative Contribution To Fluid Flow From Natural Fractures in the Cantarell Field, Mexico (SPE-122182). In Proceedings 
of Latin American and Caribbean Petroleum Engineering Conference, Cartagena de Indias, Colombia, 31 May-3 June 2009.

279. Daltaban, T.S.; Lozada, A.M.; Villavicencio, P.A.; Torres, F.M. Managing Water and Gas Production Problems in Cantarell: A Giant Carbonate Reservoir in Gulf of Mexico (SPE117233). In Proceedings of Abu Dhabi International Petroleum Exhibition and Conference, Abu Dhabi, UAE, 3-6 November 2008.

280. Beltrão, R.L.C.; Sombra, C.L.; Lage, A.C.V.M.; Fagundes Netto, J.R.; Henriques, C.C.D. Challenges and New Technologies for the Development of the Pre-Salt Cluster, Santos Basin, Brazil (OTC-19880). In Proceedings of Offshore Technology Conference, Houston, TX, USA, 4-7 May 2009.

281. Huseby, O.; Andersen, M.; Svorstol, I.; Dugstad, O. Improved Understanding of Reservoir Fluid Dynamics in the North Sea Snorre Field by Combining Tracers, 4D Seismic, and Production Data (SPE-105288). SPE Reservoir Eval. Eng. 2008, 11, 768-777.

282. Lindeloff, N.; Mogensen, K.; van Lingen, P.; Do, S.H.; Frank, S.; Noman, R. Fluid-Phase Behaviour for a Miscible-Gas-Injection EOR Project in a Giant Offshore Oil Field With Large Compositional Variations (SPE-115970). In Proceedings of SPE Annual Technical Conference and Exhibition, Denver, CO, USA, 21-24 September 2008.

283. Monahan, P. Flow Assurance Challenges for Offshore Deepwater in Republic of Congo (OTC20279). In Proceedings of Offshore Technology Conference, Houston, TX, USA, 4-7 May 2009.

284. Tealdi, L.; Obondoko, G.; Isella, D.; Baldini, D.; Baioni, A.; Okassa, F.; Pace, G.; Itoua-Konga, F.; Rampoldi, M. The Kitina Mature Offshore Field Rejuvenation: Massive Multistage Hydraulic Fracturing, Long Reach Wells, Improved Oil Recovery Techniques (SPE113609). In Proceedings of EUROPEC/EAGE Conference and Exhibition, Rome, Italy, 9-12 June 2008.

285. Gaspar, A.T.F.S.; Suslick, S.B.; Ferreira, D.F.; Lima, G.A.C. Enhanced Oil Recovery With $\mathrm{CO}_{2}$ Sequestration: A Feasibility Study of A Brazilian Mature Oil Field (SPE-94939). In Proceedings of SPE/EPA/DOE Exploration and Production Environmental Conference, Galveston, TX, USA, 7-9 March 2005.

286. Xiang, W.; Zhou, W.; Zhang, J.; Yang, G.; Jiang, W.; Sun, L.; Li, J. The Potential of $\mathrm{CO}_{2}$-EOR in China Offshore Oilfield (SPE-115060). In Proceedings of SPE Asia Pacific Oil and Gas Conference and Exhibition, Perth, Australia, 20-22 October 2008.

287. Liner, C. Carbon Capture and Sequestration: Overview and Offshore Aspects (OTC-21071). In Proceedings of Offshore Technology Conference, Houston, TX, USA, 3-6 May 2010.

288. Adetunji, L.A.; Teigland, R.; Kleppe, J. Light-Oil Air-Injection Performance: Sensitivity to Critical Parameters (SPE-96844). In Proceedings of SPE Annual Technical Conference and Exhibition, Dallas, TX, USA, 9-12 October 2005.

289. Stokka, S.; Oesthus, A.; Frangeul, J. Evaluation of Air Injection as an IOR Method for the Giant Ekofisk Chalk Field (SPE-97481). In Proceedings of SPE International Improved Oil Recovery Conference in Asia Pacific, Kuala Lumpur, Malaysia, 5-6 December 2005.

290. Blaker, T.; Aarra, M.G.; Skauge, A.; Rasmussen, L.; Celius, H.K.; Martinsen, H.A.; Vassenden, F. Foam for Gas Mobility Control in the Snorre Field: The FAWAG Project. SPE Reservoir Eval. Eng. 2002, 5, 317-323. 
291. Hernández, C.; Chacon, L.; Anselmi, L.; Angulo, R.; Manrique, E.; Romero, E.; de Audemard, N.; Carlisle, C. Single Well Chemical Tracer Test To Determine ASP (Alkaline, Surfactant, Polymer) Injection Efficiency at Lagomar VLA-6/9/21 Area, C4 Member, Lake Maracaibo, Venezuela (SPE-75122). In Proceedings of 13th SPE/DOE Improved Oil Recovery Symposium, Tulsa, OK, USA, 13-17 April 2002.

292. Manrique, E.; de Carvajal, G.; Anselmi, L.; Romero, C.; Chacon, L. Alkali/Surfactant/Polymer at VLA 6/9/21 Field in Maracaibo Lake: Experimental Results and Pilot Project Design (SPE59363). In Proceedings of SPE/DOE Improved Oil Recovery Symposium, Tulsa, OK, USA, 2-5 April 2000.

293. Othman, M.; Chong, M.O.; Sai, R.M.; Zainal, S.; Zakaria, M.S.; Yaacob, A.A. Meeting the Challenges in Alkaline Surfactant Pilot Project Implementation at Angsi Field, Offshore Malaysia (SPE-109033). Offshore Europe, Aberdeen, Scotland, U.K., Sept. 4-7, 2007.

294. Dovan, H.T.; Hutchins, R.D.; Terzian, G.A. Dos Cuadras Offshore Polymer Flood (SPE-20060). In Proceedings of SPE California Regional Meeting, Ventura, CA, USA, 4-6 April 1990.

295. Morel, D.; Vert, M.; Jouenne, S.; Nahas, E. Polymer Injection in Deep Offshore Field: The Dalia Angola Case (SPE-116672). In Proceedings of SPE Annual Technical Conference and Exhibition, Denver, CO, USA, 21-24 September 2008.

296. Han, M.; Xiang, W.; Zhang, J.; Jiang, W.; Sun, F. Application of EOR Technology by Means of Polymer Flooding in Bohai Oil Fields (SPE-104432). In Proceedings of International Oil \& Gas Conference and Exhibition, Beijing, China, 5-7 December 2006.

297. Zhou, W.; Zhang, J.; Han, M.; Xiang, W.; Feng, G.; Jiang W.; Sun, F.; Zhou, S.; Guo, Y.; Ye, Z. Application of Hydrophobically Associating Water-Soluble Polymer for Polymer Flooding in China Offshore Heavy Oilfield (IPTC-11635). In Proceedings of International Petroleum Technology Conference, Dubai, UAE, 4-6 December 2007. 


\section{Appendix}

Table 1. Summary of IOR activities in Brazil [26].

\begin{tabular}{|c|c|c|c|c|c|c|c|c|c|c|}
\hline Basin & Field & Method & Pilots & Perm. (md) & $\begin{array}{c}\text { Area } \\
\text { (acres) }\end{array}$ & Depth (ft) & $\begin{array}{c}\text { Temp. } \\
\left({ }^{\circ} \mathrm{F}\right)\end{array}$ & $\begin{array}{c}\text { Gravity } \\
\left({ }^{\circ} \mathrm{API}\right)\end{array}$ & Visc. (cp) & History Summary \\
\hline \multirow{13}{*}{ Recôncavo } & Araçás-Sergipe & $\mathrm{CO}_{2}$ & 2 & 15 & 1250 & 7400 & 225 & 40 & 1 & Started 85 Halted later \\
\hline & Araçás-Santiago & $\mathrm{CO}_{2}$ & 1 & 250 & 740 & 3940 & 140 & 30 & 3 & Started 85 Halted later \\
\hline & Buracica & Immiscible $\mathrm{CO}_{2}$ & 1 & 400 & 2000 & 1970 & 113 & 37 & 8 & Started 91 expanded \\
\hline & Rio Pojuca & $\mathrm{CO}_{2}$ & 1 & 100 & 1235 & 5900 & 176 & 38 & 3 & Started 99 expanded \\
\hline & Taquipe & $\mathrm{CO}_{2}$ & 1 & 300 & 740 & 3600 & 140 & 39 & 5 & Under study \\
\hline & Miranga & $\mathrm{CO}_{2}$ & 6 & $100-250$ & 2000 & $3280-4266$ & $140-158$ & 41 & 3 & Under study \\
\hline & D. Jaão & Alkaline & 1 & 200 & 18 & 885 & 100 & 37 & 4 & Planned 86 uninitiated \\
\hline & Buracica & Fireflood & 1 & 440 & 75 & 2300 & 120 & 35 & 11 & Started 78 Halted 80's \\
\hline & Fz. Alvorada & Steam & 1 & 500 & 740 & $590-1310$ & $95-113$ & 30 & $>10$ & Started 80's later halted \\
\hline & D. João Terra & Steam & 1 & 200 & 22 & 980 & 100 & 35 & 10 & Started 90's later halted \\
\hline & Miranga & Steam & 1 & 500 & 500 & 2300 & 122 & 18 & 900 & Started 90's later halted \\
\hline & Buracica & Polymer & 1 & 300 & 17 & 4600 & 140 & 34 & 10.5 & Started 1997 \\
\hline & Candeias & Nitrogen & 1 & 150 & 1480 & 4920 & 113 & 36 & 5 & Starts 2002 \\
\hline \multirow{7}{*}{$\begin{array}{l}\text { Sergipe- } \\
\text { Alagoas }\end{array}$} & Carmópolis & Fireflood & 3 & $220-650$ & $30-120$ & 2200 & 115 & 22 & $40-80$ & Started 78 Halted 89 \\
\hline & Carmópolis & Polymer & 1 & 200 & 10 & 2300 & 118 & 22 & 41 & Started 69 Halted 72 \\
\hline & Carmópolis & Polymer & 1 & 200 & 90 & 2300 & 118 & 22 & 50 & Started 97 \\
\hline & Carmópolis & Steam & 9 & $80-500$ & $80-190$ & 2400 & 122 & 22 & $120-300$ & Started 78 \\
\hline & Siririzinho & Steam & 1 & 230 & 15 & 1500 & 120 & 25 & 24 & Started 2000 \\
\hline & Carmópolis & MEOR & 1 & 1000 & 40 & 2300 & 118 & 22 & 50 & Starts 2002 \\
\hline & Castanhal & Steam & 1 & 4500 & 1750 & 650 & 97 & 16 & 4000 & Started 81 Halted 87 \\
\hline
\end{tabular}


Table 1. Cont.

\begin{tabular}{|c|c|c|c|c|c|c|c|c|c|c|}
\hline \multirow{14}{*}{ Potiguar } & Alto Rodríguez & Steam & 1 & 2000 & 140 & 820 & 102 & 18 & 1000 & Started 80's \\
\hline & Estreito & Steam & 2 & 3000 & 250 & 600 & 100 & 16 & $1080-2250$ & Started 80's \\
\hline & Fz. Belém & Steam & 1 & $800-7000$ & $160-1960$ & 1000 & 105 & 13.5 & $1500-3000$ & Started 80's \\
\hline & Fz. Poçinho & Steam & 2 & 500 & 10 & 1000 & 120 & $16-19$ & $1500-2000$ & Started 99 \\
\hline & Monte Alegre & Steam & 1 & $1000-1500$ & 10 & 800 & 105 & $16-20$ & $560-2100$ & Started 2000 \\
\hline & Fz. Belém & Steam+Water & 1 & 1500 & 10 & 1125 & 102 & 13.5 & $1500-3000$ & Starts 2002 \\
\hline & Alto Rodríguez & Steam+Solvent & 1 & 2000 & 15 & 900 & 105 & 15 & 10000 & Started 2001 \\
\hline & Fz. Belém & Steam+Solvent & 1 & 1500 & 1.2 & 808 & 95 & 13 & 13000 & Started 2002 \\
\hline & Canto Amaro & Polymer & 2 & 500 & 158 & 1700 & 102 & 30 & 20 & Started 2001 \\
\hline & Fz. Poçinho & Polymer & 1 & $300-500$ & 40 & 1250 & 118 & 22 & 70 & Starts 2003 \\
\hline & Estreito & Electromag. Heating & 1 & 1700 & 10 & 600 & 100 & 15 & 2000 & Started 90's \\
\hline & Fz Belém & Electromag. Heating & 1 & 1500 & 1.2 & 808 & 95 & 13 & 13000 & Started 98 \\
\hline & Canto Amaro & Electromag. Heating & 1 & $200-400$ & 10 & 1300 & 118 & 23 & 20 & Starts 2002? \\
\hline & Boa Vista & WAG & 1 & $20-500$ & 10 & 2650 & 118 & 27 & 20 & Starts $2002 ?$ \\
\hline $\begin{array}{c}\text { Espíritu } \\
\text { Santo }\end{array}$ & Fz, Alegre & Steam & 1 & 3000 & 100 & 2700 & 115 & 13 & 850 & Starts 2002? \\
\hline
\end{tabular}

(C) 2010 by the authors; licensee MDPI, Basel, Switzerland. This article is an open access article distributed under the terms and conditions of the Creative Commons Attribution license (http://creativecommons.org/licenses/by/3.0/). 